\title{
Cottonseed protein, oil, and mineral status in near-isogenic Gossypium hirsutum cotton lines expressing fuzzy/linted and fuzzless/linted seed phenotypes under field conditions
}

\section{OPEN ACCESS}

Edited by:

Antonio M. De Ron, National Spanish Research Council

(CS/C), Spain

Reviewed by: Josefina Hernández Nistal, Universidad de Santiago de

Compostela, Spain Miroslav Griga,

AGRITEC Plant Research Ltd., Czech

Republic

${ }^{*}$ Correspondence:

Nacer Bellaloui,

Crop Genetics Research Unit, Research Plant Physiologist, United

States Department of Agriculture,

Agricultural Research Service, 141 Experiment Station Road, PO Box 345

Stoneville, MS 38776, USA

nacer.bellaloui@ars.usda.gov

Specialty section:

This article was submitted to Crop Science and Horticulture, a section of the journal Frontiers in Plant Science

Received: 12 January 2015

Accepted: 20 February 2015

Published: 19 March 2015

Citation:

Bellaloui N, Stetina SR and Turley RB

(2015) Cottonseed protein, oil, and mineral status in near-isogenic

Gossypium hirsutum cotton lines expressing fuzzy/linted and fuzzless/linted seed phenotypes under field conditions.

Front. Plant Sci. 6:137. doi: 10.3389/fp/s.2015.00137

\author{
Nacer Bellaloui*, Salliana R. Stetina and Rickie B. Turley
}

Crop Genetics Research Unit, Plant Physiology, United States Department of Agriculture, Agricultural Research Service, Stoneville, MS, USA

Cotton is an important crop in the world and is a major source of oil for human consumption and cotton meal for livestock. Cottonseed nutrition (seed composition: protein, oil, and minerals) determines the quality of seeds. Therefore, maintaining optimum levels of cottonseed nutrition is critical. Physiological and genetic mechanisms controlling the levels of these constituents in cottonseed are still largely unknown. Our previous research conducted under greenhouse conditions showed that seed and leaf nutrition differed between fuzzless and fuzzy seed isolines. Therefore, the objective of this research was to investigate the seed fuzz phenotype (trait) effects on seed protein, oil, N, C, S, and minerals in five sets of near-isogenic mutant cotton lines for seed fuzz in a 2-year experiment under field condition to evaluate the stability of the effect of the trait on seed nutrition. The isolines (genotypes) in each set differ for the seed fuzz trait (fuzzless/linted seed line, $N$ lines, and fuzzy/linted seed line, $F$ lines). Results showed that seed protein was higher in the fuzzy genotype in all sets, but seed oil was higher in fuzzless genotype in all sets. The concentrations of seed $\mathrm{Ca}$ and $\mathrm{C}$ were higher in all fuzzless genotypes, but N, S, B, Fe, and Zn were higher in most of the fuzzy genotypes. Generally, minerals were higher in leaves of $F$ lines, suggesting the translocation of minerals from leaves to seeds was limited. The research demonstrated that fiber development could be involved in cottonseed composition. This may be due to the involvement of fiber development in carbon and nitrogen metabolism, and the mobility of nutrients from leaves (source) to seed (sink). This information is beneficial to breeders to consider fuzzless cottonseed for potential protein and oil use and select for higher oil or higher protein content, and to physiologists to further understand the mobility of minerals to increase the quality of cottonseed nutrition for food and feed.

Keywords: cottonseed protein, cottonseed oil, cottonseed composition, minerals, near-isogenic cotton, cotton mutants 


\section{Introduction}

Cotton is a major crop in the world (Yu et al., 2012). Cotton fiber is a source of natural textile, and cottonseed is a source of oil for human consumption, cotton meal and minerals for livestock feed (Yu et al., 2012; He et al., 2013). Therefore, maintaining high quality fiber and cottonseed nutritional value is critical. There are four cultivated cotton species, Gossypium hirsutum (about $95 \%$ of the cultivated cotton), G. barbadense, G. arboreum, and G. herbaceum together (the last three represent about 5\%) (Turley et al., 2007; Padmalatha et al., 2012; Bellaloui and Turley, 2013; Stetina et al., 2014). Cotton fibers are developed from the ovule epidermis and are single-celled seed trichomes, and about $30 \%$ of the seed epidermal cells differentiate into spinable fibers (Arpat et al., 2004; Wilkins and Arpat, 2005). The development of cotton fibers comprises four stages named fiber cell initiation, fiber cell elongation/primary cell wall (occurs up to 20 days postanthesis), fiber cell synthesis/secondary cell wall (occurs between 5 and 15 days post-anthesis, and the secondary cell wall synthesis begins at about 20 days post-anthesis and reaches up to 45 days post-anthesis), and maturation (occurs from 45 to 50 days postanthesis) where fibers dehydrate and produce mature cotton lint (Ji et al., 2003; Arpat et al., 2004; Wilkins and Arpat, 2005).

Upland cotton (Gossypium hirsutum) is the predominant species commercially cultivated in the United States and produces two types of fiber on cottonseed, lint and fuzz. Lint fiber is economically valuable, and it is longer and develops faster than the fuzz (Stewart, 1975; Seagull and Giavalis, 2004; Stetina et al., 2014). During ginning process, lint fiber is removed and fuzz fiber left behind (Bechere et al., 2009). There are two naturally occurring mutations in cotton allowing the development of lint fiber, but preventing development of fuzz fiber, and these are referred to as the fuzzless seed alleles and designated as genotypes $N_{1-}$ (dominant fuzzless allele) or $n_{2} n_{2}$ (recessive fuzzless allele) (Turley and Kloth, 2002; Turley et al., 2007; Stetina et al., 2014).

It is reported that the fuzzless trait in cottonseed is a novel tool to use to understand the biology, genetics, and biochemical and metabolic processes (Turley et al., 2007; Padmalatha et al., 2012). In spite of the few reports available on the effects of fuzzless trait on the biology, genetics, and molecular biology (Padmalatha et al., 2012), very limited information is available on the effects of fuzzless trait on cottonseed composition (Yu et al., 2012; Bellaloui and Turley, 2013; He et al., 2013). For example, the effect of fuzzless trait was investigated on genetic products (Turley and Kloth, 2002; Gou et al., 2007; Turley et al., 2007; Zhao et al., 2009; Pang et al., 2010a,b; Liu et al., 2012), physiological (Ruan et al., 2003; Shi et al., 2006; Yang et al., 2006; Wang et al., 2010; Wang and Ruan, 2010; Zhang et al., 2011), and molecular (Machado et al., 2009; Guan et al., 2011; Walford et al., 2011). It was also reported that carbohydrate and energy metabolisms are involved in fiber development and carbon skeletons for the synthesis of cell wall polysaccharides and fatty acids (Gou et al., 2007; Yang et al., 2008; Pang et al., 2010a,b), and actin cytoskeleton to trigger the secondary cell wall synthesis (Li et al., 2002, 2005; Wang et al., 2010; Wang and Ruan, 2010).

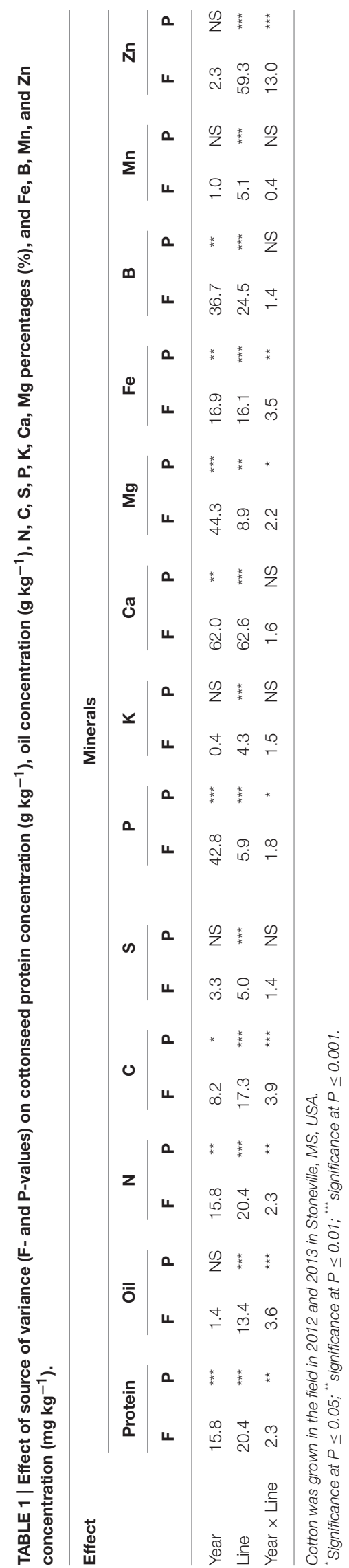




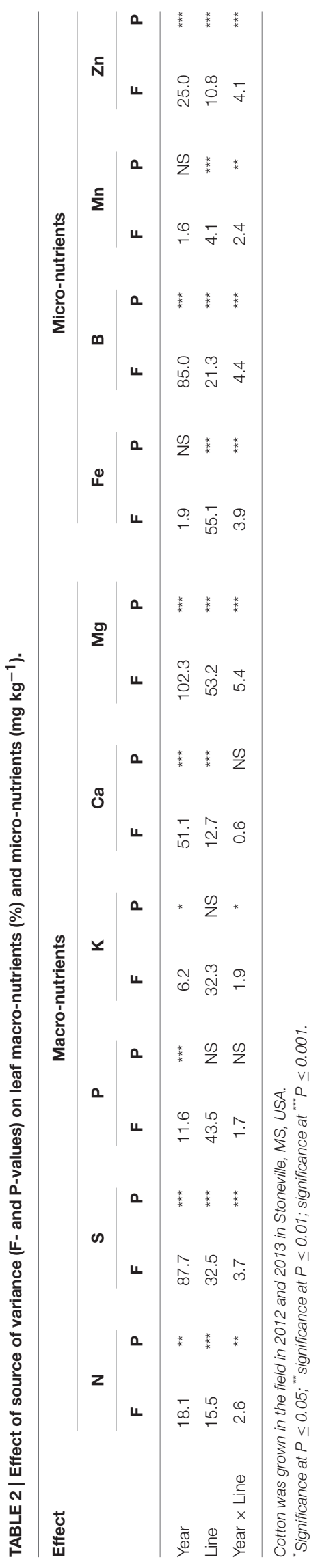

Cottonseed quality is also determined by its content of mineral and non-mineral nutrients such as $\mathrm{N}, \mathrm{C}, \mathrm{S}, \mathrm{K}, \mathrm{Ca}, \mathrm{Zn}$, and $\mathrm{Fe}$ because of their direct or indirect contribution to: protein synthesis (such as $\mathrm{N}, \mathrm{K}, \mathrm{S}$ ); oil (such as $\mathrm{C}$ and $\mathrm{N}$ ); carbohydrates (such as $\mathrm{C}, \mathrm{K}, \mathrm{B}$ ); metabolite synthesis $(\mathrm{Cu}, \mathrm{Zn}$, $\mathrm{Fe}, \mathrm{Mg}$ ); integrity of cell membrane and cell wall structure (Ca and B); cell membrane, lipid synthesis, energy transfer and phosphorylation reactions, carbohydrate metabolism, and nutrient active uptake processes (P); and osmoregulation, stomatal closure, carbohydrate movement, and nutrient mobility (K). The physiological and biochemical roles of these nutrients in plant growth and development were previously reported (Mengel and Kirkby, 1982; Marschner, 2012). The benefit of minerals to human health was also previously reported. For example, an unbalanced diet of micronutrients such as $\mathrm{Fe}, \mathrm{Zn}$, leads to human malnutrition (Samman et al., 1998; Fletcher et al., 2004; Lu et al., 2008). Therefore, maintaining an optimum level of $\mathrm{Fe}, \mathrm{Zn}, \mathrm{Cu}, \mathrm{Mo}, \mathrm{Mn}$ (Zhang et al., 2004; Heinemann et al., 2005) in seeds of major crops that are used for protein and oil sources is critical. It was reported that nutrient uptake, translocation, redistribution, and accumulation are processes controlling the concentrations of minerals in seeds (Grusak and DellaPenna, 1999; White and Broadley, 2005), and most of the genetic basis of these process are not known (Ding et al., 2010).

To our knowledge this is the first comprehensive report to use near-isogenic cotton mutant genotypes for the fuzzless trait to evaluate its effects on cottonseed nutrition (protein, oil, $\mathrm{N}, \mathrm{S}, \mathrm{C}$, and minerals) under field conditions. Our hypothesis was that because several metabolic processes including carbon metabolism and polysaccharide cell wall synthesis are involved in fiber development (Li et al., 2002, 2005; Gou et al., 2007; Yang et al., 2008; Wang et al., 2010; Wang and Ruan, 2010; Pang et al., 2010a,b), cottonseed nutrition will be influenced as protein and oil are results of carbon, nitrogen, and carbohydrate metabolism. Since we observed differences in leaf and seed nutrients between lines, we hypothesized that nutrients in lint fiber may be impacted as well. Therefore, we investigated the effect of fuzz trait on nutrient content in lint for 1 year only to obtain preliminary results for future research planning.

\section{Materials and Methods}

\section{Germplasm Development}

The development of near-isogenic lines was described in detail elsewhere (Stetina et al., 2014). The near-isogenic lines (NILs), one expressing the fuzzy/linted and one expressing fuzzless/linted phenotype were developed in five upland cotton backgrounds (Stetina et al., 2014). The following are five sets of $F$ and $N$ lines/genotypes: Sure-Grow (SG) 747 F vs. SG 747 N; MD51ne $F$ vs. MD51ne N; STV 7 A $g l F$ vs. STV 7 A $g l ~ N$; DP $5690 F$ vs. DP $5690 \mathrm{~N}$; DES $119 \mathrm{~F}$ vs. DES $119 \mathrm{~N}$. Genotype SA 243 ("Ballard naked seed," PI 528610) was the fuzzless parent with the dominant fuzzless seed allele, $N_{1} N_{1}$ (Turley et al., 2007), and DP 444 BG/RR (Monsanto Company, St. Louis, MO, USA) was used as the commercial check. 
TABLE 3 | Effect of fuzzless/linted $(N)$ and fuzzy/linted $(F)$ cottonseed phenotypes on cottonseed protein concentration ( $\mathrm{g}$ kg ${ }^{-1}$ ), oil concentration ( $\mathrm{g}$ $\mathrm{kg}^{-1}$ ), N, C, S, P, K, Ca, Mg percentages (\%), and Fe, B, Mn, and Zn concentration ( $\mathrm{mg} \mathrm{kg}^{-1}$ ).

\begin{tabular}{|c|c|c|c|c|c|c|c|c|c|c|c|c|c|}
\hline Line/genotype & Protein & Oil & C & $\mathbf{N}$ & $\mathbf{S}$ & Ca & $\mathbf{K}$ & Mg & $\mathbf{P}$ & B & $\mathrm{Fe}$ & Mn & $\mathbf{Z n}$ \\
\hline SA 243 & 226 ef & 270 ef & $51.3 \mathrm{~d}$ & $3.27 \mathrm{~g}$ & $0.26 \mathrm{e}$ & $0.13 f$ & 0.94 e & $0.34 \mathrm{~g}$ & $0.56 \mathrm{~g}$ & $10.0 \mathrm{f}$ & $44.3 \mathrm{e}$ & $13.4 \mathrm{c}$ & $29.9 \mathrm{e}$ \\
\hline DP 444 BG/RR & $287 a$ & $282 \mathrm{~cd}$ & $51.3 \mathrm{~d}$ & $4.10 \mathrm{bc}$ & $0.34 \mathrm{c}$ & 0.14 e & $1.03 \mathrm{bc}$ & $0.40 \mathrm{~b}$ & $0.64 \mathrm{bc}$ & $12.8 \mathrm{a}$ & $52.8 \mathrm{~b}$ & $13.3 \mathrm{~cd}$ & $56.9 \mathrm{c}$ \\
\hline DES $119 N$ & $240 d$ & 293 b & $52.8 \mathrm{~b}$ & 3.48 ef & $0.30 \mathrm{~d}$ & $0.18 \mathrm{a}$ & 0.95 e & $0.41 b$ & $0.65 \mathrm{~b}$ & $11.7 \mathrm{~b}$ & $49.0 \mathrm{c}$ & $14.0 \mathrm{~b}$ & $33.9 \mathrm{e}$ \\
\hline DES $119 F$ & $276 b$ & $260 \mathrm{fg}$ & 50.8 e & $4.32 \mathrm{a}$ & $0.40 \mathrm{a}$ & $0.12 \mathrm{~g}$ & 1.05 b & $0.43 \mathrm{a}$ & $0.72 \mathrm{a}$ & $12.8 \mathrm{a}$ & $62.4 \mathrm{a}$ & $14.6 \mathrm{a}$ & $81.7 \mathrm{a}$ \\
\hline DP $5690 N$ & $217 \mathrm{~g}$ & 323 a & $53.3 \mathrm{a}$ & $3.25 \mathrm{~g}$ & 0.27 e & $0.15 \mathrm{c}$ & $0.91 \mathrm{f}$ & $0.35 \mathrm{f}$ & $0.55 \mathrm{~g}$ & $9.3 \mathrm{~g}$ & $39.9 \mathrm{~g}$ & $12.2 \mathrm{f}$ & $25.9 f$ \\
\hline DP $5690 F$ & 252 c & $275 \mathrm{fg}$ & 50.9 e & $3.95 \mathrm{c}$ & $0.37 \mathrm{~b}$ & $0.11 \mathrm{~h}$ & $0.99 \mathrm{~d}$ & $0.38 \mathrm{~cd}$ & $0.59 \mathrm{f}$ & $11.6 \mathrm{~b}$ & $48.7 \mathrm{~cd}$ & $11.5 \mathrm{~g}$ & $76.8 \mathrm{~b}$ \\
\hline MD 51ne N & $221 \mathrm{fg}$ & $274 \mathrm{fg}$ & $52.2 \mathrm{c}$ & $3.27 \mathrm{~g}$ & $0.26 \mathrm{e}$ & $0.18 \mathrm{a}$ & 0.95 e & $0.37 \mathrm{e}$ & 0.59 ef & $10.7 \mathrm{~d}$ & $44.6 \mathrm{e}$ & $13.6 \mathrm{c}$ & $30.8 \mathrm{e}$ \\
\hline MD 51ne $F$ & $274 b$ & $257 \mathrm{gh}$ & 50.9 e & $4.15 \mathrm{ab}$ & $0.35 \mathrm{bc}$ & $0.14 d$ & 1.05 bc & $0.39 \mathrm{c}$ & $0.62 \mathrm{~cd}$ & $11.7 \mathrm{~b}$ & $50.6 \mathrm{c}$ & $12.2 f$ & $75.6 \mathrm{~b}$ \\
\hline SG $747 N$ & 229 e & $288 \mathrm{bc}$ & $52.1 \mathrm{c}$ & $3.31 \mathrm{fg}$ & $0.26 \mathrm{e}$ & $0.17 b$ & 0.94 e & 0.37 de & $0.61 \mathrm{de}$ & $11.0 \mathrm{c}$ & $42.2 \mathrm{f}$ & 12.9 de & $31.2 \mathrm{e}$ \\
\hline SG $747 F$ & $285 a$ & $250 \mathrm{~h}$ & $50.3 \mathrm{~g}$ & $4.11 \mathrm{bc}$ & $0.31 d$ & $0.12 \mathrm{fg}$ & 1.02 c & $0.38 \mathrm{c}$ & $0.65 \mathrm{bc}$ & $12.9 \mathrm{a}$ & $50.1 \mathrm{c}$ & $12.7 \mathrm{e}$ & $50.7 \mathrm{~d}$ \\
\hline STV $7 A g / N$ & $197 \mathrm{~h}$ & 264 e & $52.7 \mathrm{~b}$ & 3.57 de & $0.26 \mathrm{e}$ & $0.15 \mathrm{c}$ & 0.95 e & $0.38 \mathrm{~cd}$ & 0.59 ef & 10.4 e & $39.3 \mathrm{~g}$ & $11.3 \mathrm{~g}$ & 30.0 ef \\
\hline STV 7Agl F & $255 c$ & $234 \mathrm{i}$ & $50.5 f$ & $3.72 \mathrm{~d}$ & $0.30 \mathrm{~d}$ & $0.11 \mathrm{~h}$ & $1.10 \mathrm{a}$ & $0.40 \mathrm{~b}$ & $0.65 \mathrm{~b}$ & $11.8 \mathrm{~b}$ & $47.0 \mathrm{~d}$ & $11.4 \mathrm{~g}$ & $55.9 \mathrm{c}$ \\
\hline
\end{tabular}

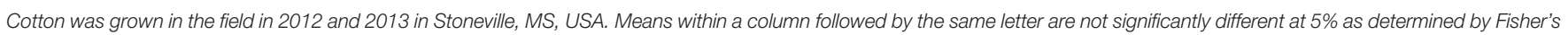
LSD test.

TABLE 4 | Effect of fuzzless/linted $(N)$ and fuzzy/linted $(F)$ cottonseed phenotypes on leaf $\mathrm{Ca}, \mathrm{K}, \mathrm{Mg}, \mathrm{P}, \mathrm{N}$, and $\mathrm{S}$ percentages (\%), and B, Fe Mn, and Zn concentration $\left(\mathrm{mg} \mathrm{kg}^{-1}\right)$.

\begin{tabular}{|c|c|c|c|c|c|c|c|c|c|c|}
\hline Line/genotype & Ca & $\mathbf{K}$ & Mg & $\mathbf{P}$ & $\mathbf{N}$ & $\mathbf{S}$ & B & $\mathrm{Fe}$ & Mn & $\mathbf{Z n}$ \\
\hline SA 243 & 3.39 de & $2.01 \mathrm{f}$ & $1.09 \mathrm{c}$ & $0.42 \mathrm{~g}$ & $4.23 d$ & $0.96 \mathrm{e}$ & 40.9 e & $78.6 \mathrm{~g}$ & $166.6 \mathrm{~cd}$ & $37.4 \mathrm{~d}$ \\
\hline DP 444 BG/RR & $3.36 \mathrm{e}$ & $1.88 \mathrm{~g}$ & $0.95 d$ & $0.39 \mathrm{~h}$ & $3.84 \mathrm{f}$ & $0.84 \mathrm{f}$ & $40.2 \mathrm{e}$ & $77.6 \mathrm{~g}$ & $158.3 \mathrm{f}$ & $37.4 \mathrm{~cd}$ \\
\hline DES $119 N$ & $4.31 b$ & $3.48 \mathrm{~b}$ & $1.22 \mathrm{~b}$ & $0.75 \mathrm{a}$ & $4.41 \mathrm{C}$ & $1.61 \mathrm{~b}$ & $51.9 b$ & $120.2 \mathrm{~b}$ & $170.8 b$ & $42.4 \mathrm{a}$ \\
\hline DES $119 F$ & $3.09 \mathrm{f}$ & $2.38 \mathrm{e}$ & 0.78 e & $0.58 d$ & $3.40 \mathrm{~g}$ & $0.96 \mathrm{e}$ & $40.2 \mathrm{e}$ & $90.1 \mathrm{de}$ & $172.8 \mathrm{ab}$ & $30.8 \mathrm{e}$ \\
\hline DP $5690 N$ & $3.58 \mathrm{~cd}$ & $2.78 \mathrm{c}$ & $1.00 \mathrm{~d}$ & $0.65 \mathrm{c}$ & $4.04 \mathrm{c}$ & $1.70 \mathrm{a}$ & $48.0 \mathrm{c}$ & $91.3 \mathrm{~d}$ & $173.3 \mathrm{a}$ & $39.0 \mathrm{~b}$ \\
\hline DP $5690 F$ & $3.68 \mathrm{c}$ & $1.70 \mathrm{~h}$ & $0.67 \mathrm{f}$ & $0.65 \mathrm{c}$ & $3.80 \mathrm{c}$ & $1.31 \mathrm{~d}$ & $41.3 \mathrm{e}$ & $87.2 \mathrm{e}$ & $167.8 \mathrm{c}$ & $37.4 \mathrm{~d}$ \\
\hline MD 51ne N & $4.70 \mathrm{a}$ & $2.84 \mathrm{c}$ & $1.68 \mathrm{a}$ & $0.70 \mathrm{~b}$ & $4.90 \mathrm{~b}$ & $1.54 \mathrm{~b}$ & $55.1 \mathrm{a}$ & $141.0 \mathrm{a}$ & 162.3 e & $42.3 \mathrm{a}$ \\
\hline MD 51ne $F$ & $3.66 \mathrm{c}$ & $1.55 \mathrm{i}$ & $0.98 d$ & $0.51 \mathrm{f}$ & $3.80 \mathrm{f}$ & 0.97 e & $43.3 \mathrm{~d}$ & $117.2 \mathrm{~b}$ & 162.0 e & $31.6 \mathrm{e}$ \\
\hline SG $747 N$ & $4.45 b$ & $2.61 \mathrm{~d}$ & $1.61 \mathrm{a}$ & $0.64 \mathrm{c}$ & $4.60 \mathrm{~b}$ & $1.42 \mathrm{c}$ & $50.7 \mathrm{~b}$ & $119.7 \mathrm{~b}$ & $165.1 \mathrm{~d}$ & $43.5 \mathrm{a}$ \\
\hline SG $747 F$ & 3.38 e & $1.60 \mathrm{hi}$ & $0.93 d$ & $0.43 \mathrm{~g}$ & $3.81 \mathrm{f}$ & 0.89 ef & 40.3 e & $82.0 \mathrm{f}$ & $167.9 \mathrm{c}$ & $36.7 \mathrm{~d}$ \\
\hline STV $7 A g / N$ & $4.88 \mathrm{a}$ & $3.81 \mathrm{a}$ & $1.22 \mathrm{~b}$ & $0.75 a$ & $4.81 \mathrm{a}$ & $1.38 \mathrm{~cd}$ & $50.3 b$ & $139.4 \mathrm{a}$ & $162.5 \mathrm{e}$ & $37.2 \mathrm{~d}$ \\
\hline STV 7Agl F & 3.40 de & $2.48 \mathrm{e}$ & $0.75 \mathrm{e}$ & $0.55 \mathrm{e}$ & $2.98 \mathrm{~h}$ & $0.85 f$ & $40.2 \mathrm{f}$ & 107.2 c & $162.5 \mathrm{e}$ & $38.8 \mathrm{bc}$ \\
\hline
\end{tabular}

Cotton was grown in the field in 2012 and 2013 in Stoneville, MS, USA.

Means within a column followed by the same letter are not significantly different at $5 \%$ as determined by Fisher's LSD test.

\section{Field Management and Growth Conditions}

A field experiment was conducted in 2012 and 2013 at Stoneville, MS, USA. Field management and growth conditions were previously detailed in Stetina et al. (2014). Briefly, cottonseeds were planted on four-row plots spaced $1.02 \mathrm{~m}$ apart and each plot was $9.14 \mathrm{~m}$ long with a $3.04 \mathrm{~m}$ alley between plots. Planting dates were 25 April 2012 and 13 May 2013. Insecticides and fungicides were applied to control pest and diseases. Field management was conducted according to the standard agronomic practices for cotton production in the Mississippi Delta region (http://msucares.com/crops/cotton/index.html). Cotton bolls were harvested from 10 adjacent plants at three (2012) and four (2013) intervals to prevent the loss of fuzzless cottonseed content due to rain and wind. The harvest intervals were on 28 August, 6 September, and 27 September in 2012, and on 5 September, 12 September, 17 September, and 27 September in
2013. A defoliant was used prior to the last harvest date each year. Cottonseed samples were processed at the USDA ARS Cotton Ginning Laboratory at Stoneville, MS, USA and saw-ginned on 20 November 2012 and 12 November 2013. Cottonseed were collected and acid-delinted for seed composition analyses. Soil samples were taken across the field by dividing the field into four main sections and taking 20-25 samples from each section at depth of $30.5 \mathrm{~cm}$. Therefore, one composite sample (combined 20-25 samples) represented each section. Analysis of the four samples, representing the four sections, showed uniformity in main soil nutrients. Therefore, the soil nutrients shown in here are average of the four sections representing the entire field. For leaf sampling, the most recent fully expanded leaves were taken from each plot. Fourteen leaves were taken from the middle two rows (7 leaves were taken along each one middle row to ensure equal distribution of leaves along each row). Leaves were 
oven-dried at $65^{\circ} \mathrm{C}$ and ground into fine particle with Laboratory Mill 3600 (Perten, Springfield, IL). Seed and leaf C, N, K, Ca, Mn, and $\mathrm{Zn}$ were analyzed at the University of Georgia's Soil, Plant, and Water Laboratory, Athens, GA. Seed protein, oil, B, Fe, P, and leaf $\mathrm{B}, \mathrm{Fe}$, and $\mathrm{P}$ were analyzed as described below.

\section{Boron Analysis}

Boron concentrations in the most recently fully expanded leaves at boll stage and mature seeds were determined according to Lohse (1982) using the azomethine- $\mathrm{H}$ method, and samples were prepared according to John et al. (1975). Boron concentration was determined spectrophotometrically by reading the samples at $420 \mathrm{~nm}$ using a Beckman Coulter DU 800 spectrophotometer (Fullerton, CA). The concentration of B was measured after color development, and B concentration was expressed as $\mathrm{mg} \mathrm{B} \mathrm{kg}^{-1} \mathrm{dwt}$.

\section{Iron Analysis}

Iron concentrations in the most recently fully expanded leaves at boll stage and mature seeds were measured according to Bandemer and Schaible (1944) and Loeppert and Inskeep (1996). The concentration was determined by acid wet digestion (Analytical Methods Committee, 1959), extraction, and reaction of the

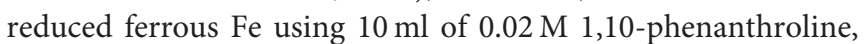
and the samples were prepared for measurement using a quinol solution of $1 \%(\mathrm{w} / \mathrm{v})$ reagent. Concentrations of $\mathrm{Fe}$ in leaves and seeds were measured spectrophotometrically at $510 \mathrm{~nm}$ using a Beckman Coulter DU 800 spectrophotometer (Fullerton,

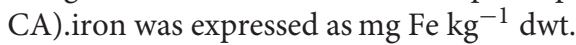

\section{Phosphorus Analysis}

Phosphorus concentrations in leaves and mature seeds were determined according to Cavell (1955) using the yellow phosphor-vanado-molybdate complex. Briefly, $2 \mathrm{~g}$ of dried ground samples were ashed and $10 \mathrm{ml}$ of $6 \mathrm{M} \mathrm{HCl}$ was added. The samples, then were placed in a water bath to evaporate the solution to dryness. Then, a $2 \mathrm{ml}$ of $36 \% \mathrm{v} / \mathrm{v} \mathrm{HCl}$ was added and the samples were boiled. Ten milliliters of distilled water was added to the samples and the solution was brought to boil for a few seconds, and then diluted to $50 \mathrm{ml}$ with distilled water, and then filtered. To measure $\mathrm{P}$ concentration, a reagent of $5 \mathrm{ml}$ of $5 \mathrm{M} \mathrm{HCl}$ and $5 \mathrm{ml}$ of ammonium molybdate-ammonium metavanadate was freshly prepared and added to the filtrate. The concentration of $\mathrm{P}$ was measured spectrophotometrically using a Beckman Coulter DU 800 spectrophotometer at $400 \mathrm{~nm}$. The concentration of $\mathrm{P}$ in the sample was expressed as a percentage.

\section{Analyses of N, S, C in Leaves and Seed}

The most recently fully expanded leaves during boll stage and mature seeds were analyzed for minerals, N, S, and C concentrations by digesting $0.6 \mathrm{~g}$ of dried, ground seed in $\mathrm{HNO}_{3}$ in a microwave digestion system. The concentrations of minerals in the samples were determined using inductively coupled plasma spectrometry (ICP) (Bellaloui and Turley, 2013; Bellaloui et al., 2014). For N, S, and C measurements, a 0.25 g ground-dried sample was combusted in an oxygen atmosphere at $1350^{\circ} \mathrm{C}$ to convert elemental N, S, and N, S, and C were measured by an elemental
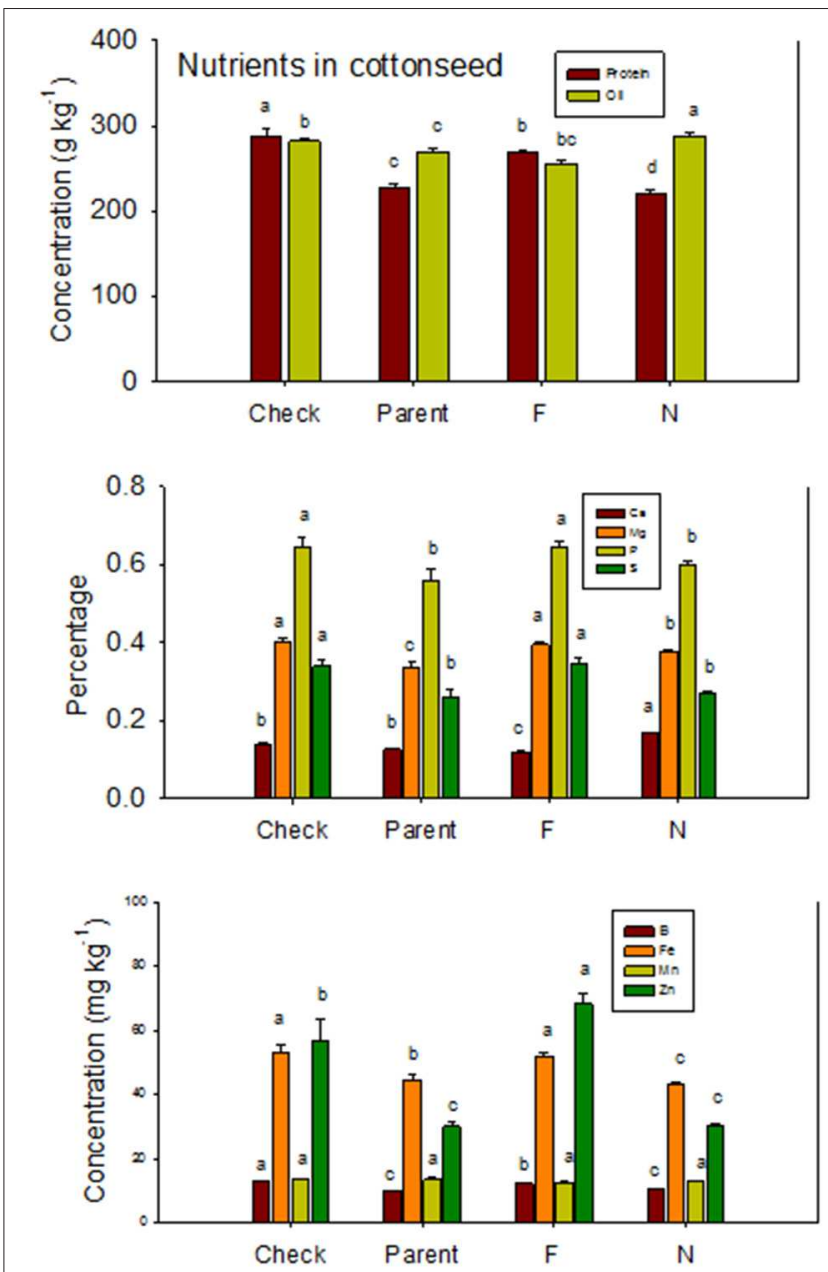

FIGURE 1 | Effects of cottonseed fuzz trait on cottonseed protein, oil, and nutrients in near-isogenic Gossypium hirsutum lines expressing fuzzy/linted $(F)$ and fuzzless/linted $(N)$ seed phenotypes, the fuzzless/linted parent SA 243 (parent), and the fuzzy/linted commercial cultivar DP 444 BG/RR (check). Cotton was grown in the field in 2012 and 2013 in Stoneville, MS, USA. Bars show means \pm standard error of the mean (SE). Within each constituent, means with the same letter are not significantly different at $5 \%$ as determined by Fisher's LSD test.

analyzer using thermal conductivity cells (LECOCNS-2000 Elemental Analyzer, LECO Corporation, St. Joseph, MI) (Bellaloui et al., 2011, 2014).

\section{Analyses of Minerals, N, S, and C in Soil}

Mineral concentrations in soil, N, S, and C were analyzed at The University of Georgia's Soil, Plant, and Water Laboratory, Athens, GA. The concentrations of the minerals $\mathrm{K}$ and Mn were determined using a 5-g soil: $20 \mathrm{ml}$ Mehlich-1 solution and analyzed using inductively coupled plasma (ICP) spectrometry (Bellaloui et al., 2009). Percentages of N, S, and C were determined in a 0.25 -g sample of soil by combusting samples in an oxygen atmosphere at $1350^{\circ} \mathrm{C}$, and converting elemental $\mathrm{N}, \mathrm{S}$, and $\mathrm{C}$ into $\mathrm{N}_{2}, \mathrm{SO}_{2}$, and $\mathrm{CO}_{2}$ gasses, and $\mathrm{N}, \mathrm{S}$, and $\mathrm{C}$ were determined by elemental analyzer using thermal conductivity cells (LECOCNS2000 Elemental Analyzer LECO Corporation, St. Joseph, MI, 

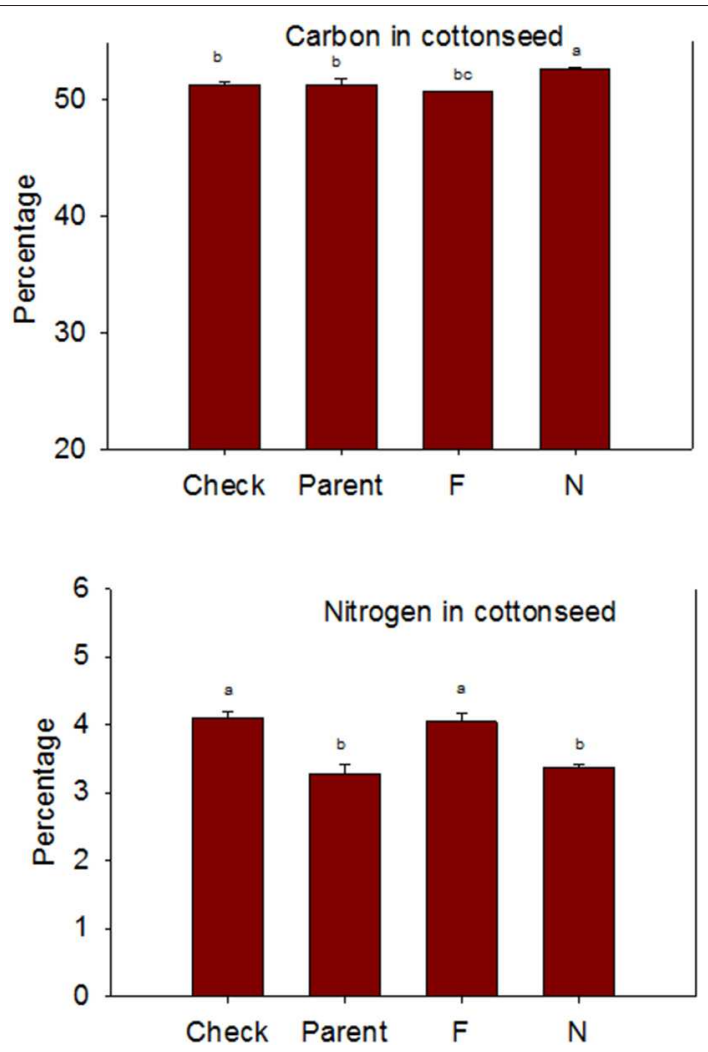

FIGURE 2 | Effects of cottonseed fuzz trait on cottonseed carbon (C) and nitrogen $(\mathrm{N})$ in near-isogenic Gossypium hirsutum lines expressing fuzzy/linted $(F)$ and fuzzless/linted $(N)$ seed phenotypes, the

fuzzless/linted parent SA 243 (parent), and the fuzzy/linted commercial cultivar DP 444 BG/RR (check). Cotton was grown in the field in 2012 and 2013 in Stoneville, MS, USA. Bars show means \pm standard error of the mean (SE). Within each constituent, means with the same letter are not significantly different at $5 \%$ as determined by Fisher's LSD test.

USA) (Bellaloui et al., 2009). Concentrations of N, S, and C were expressed as percentages.

\section{Cottonseed Protein and Oil Analysis}

Mature cottonseeds were collected from each plot and analyzed for protein and oil. Briefly, approximately $25 \mathrm{~g}$ of seed was ground using a Laboratory Mill 3600 (Perten, Springfield, IL). Protein and oil in cottonseed were analyzed by near infrared reflectance according to Wilcox and Shibles (2001) and Bellaloui and Turley (2013) using a diode array feed analyzer AD 7200 (Perten, Springfield, IL). Calibrations were developed using Perten's Thermo Galactic Grams PLS IQ software, and the calibration equation was established according to AOAC methods (Association of Official Analytical Chemists (AOAC), 1990a,b). Cottonseed protein and oil were expressed on a seed dry matter basis (Wilcox and Shibles, 2001; Boydak et al., 2002; Bellaloui and Turley, 2013).

\section{Experimental Design and Data Analysis}

This experiment was a part of a large experiment that was designed in a split-plot. The main plot was line (genotype),
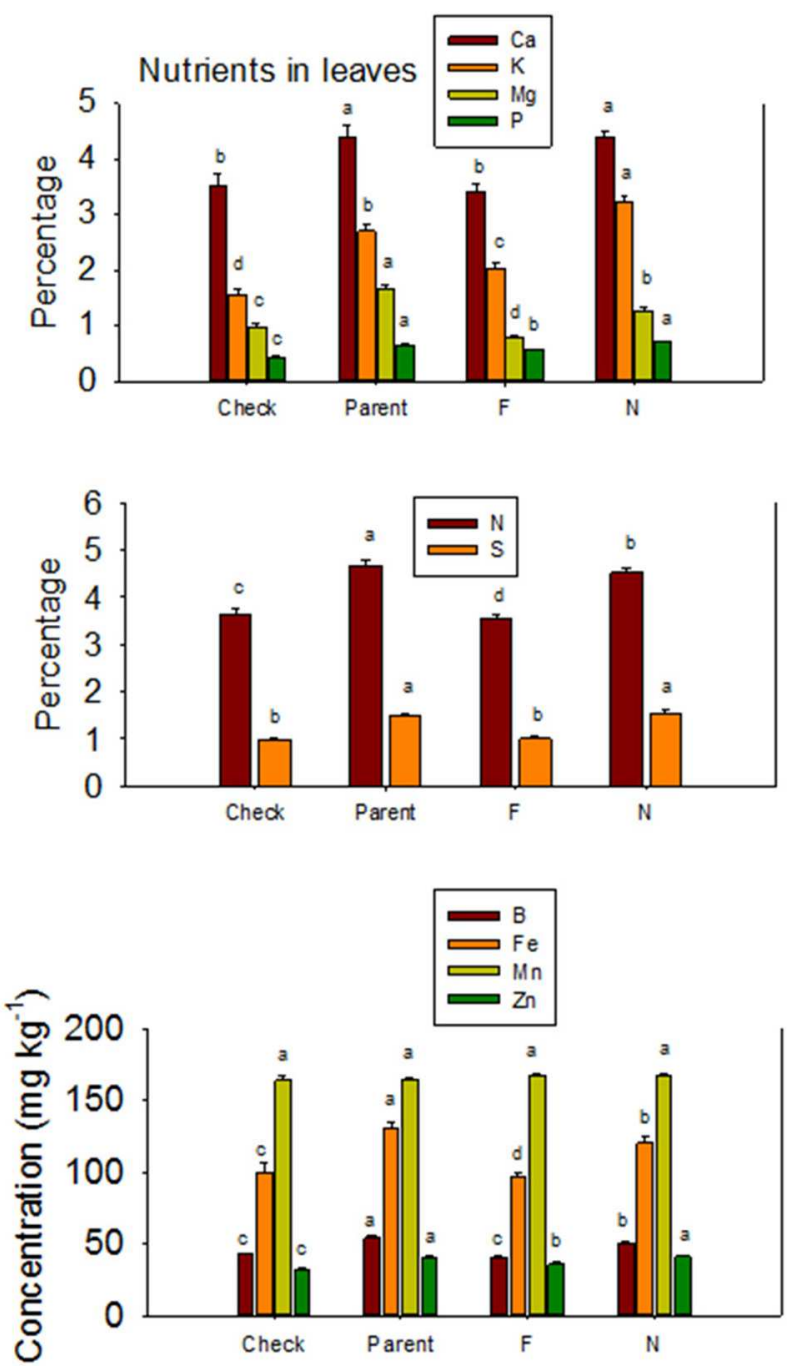

FIGURE 3 | Effects of cottonseed fuzz trait on cotton leaf nutrients in near-isogenic Gossypium hirsutum lines expressing fuzzy/linted $(F)$ and fuzzless/linted $(N)$ seed phenotypes, the fuzzless/linted parent SA 243 (parent), and the fuzzy/linted commercial cultivar DP 444 BG/RR (check). Cotton was grown in the field in 2012 and 2013 in Stoneville, MS, USA. Bars show means \pm standard error of the mean (SE). Within each constituent, means with the same letter are not significantly different at $5 \%$ as determined by Fisher's LSD test.

and plots were arranged in a randomized complete block design with 4 replications. The subplot was ginning method (Stetina et al., 2014). In the current study, we were interested in the conventional saw ginning method only. Therefore, the only factors under the study were line, year, and their interactions. Analysis of variance was conducted using Proc Mixed model in SAS (Statistical Analysis System; SAS Institute, Inc., Cary, NC, 2002-2012). Year (Y), Line, and Y $\times$ Line interactions were modeled as fixed effects, and replicates and their interactions were considered random effects. Means were separated by Fisher's protected least significant difference test at the 5\% level of significance using SAS (2002-2012). 
Correlation was performed using PROC CORR in SAS (2002-2012).

\section{Results and Discussion}

\section{Analysis of Variance}

ANOVA showed that year and line were the major sources of variability for seed composition constituents (Table 1). Based on Fvalue, year is more important for some constituents such as $\mathrm{P}, \mathrm{Mg}$, and $\mathrm{B}$ than line, suggesting that growing season may have also an influence on these constituents. For others constituents such as protein, $\mathrm{N}, \mathrm{C}$, and $\mathrm{Zn}$, genotypic effects were more important than year effects, suggesting the significant effects of genetic factors in controlling the accumulation of these constituents. There were no significant effects of year on oil, $\mathrm{S}, \mathrm{K}$, and $\mathrm{Mn}$, suggesting that the response of these constituents was similar in each year. All constituents were influenced by line, but the magnitude of the accumulation in seeds differed, depending on the line. For leaf $\mathrm{N}$, S, and minerals (Table 2), year was significant for all nutrients, except for Fe and Mn. Line had significant effects for all nutrients, except for $\mathrm{P}$ and $\mathrm{K}$, suggesting that the levels of nutrients in leaves were significantly influenced by the line. Since the $F$-value of year $\times$ line interactions was smaller (less significant: its contribution to the model was smaller) compared with that of the main effect of year or line, the data were combined across the 2 years.

\section{Effects of Fuzz Trait on Seed and Leaf Composition}

Lines with fuzzy seeds $(F)$ had higher concentrations of seed protein, $\mathrm{N}$ and $\mathrm{S}$ than lines with fuzzless seeds $(N)$ (with exception of STV 7Agl N), but $N$ lines had higher oil and C than in seeds of $F$ lines (Table 3). Calcium levels in seed were higher in $N$ lines than in $F$ lines. Minerals $\mathrm{K}, \mathrm{Mg}, \mathrm{P}$, and $\mathrm{Zn}$ in seeds were higher in $F$ lines than in $N$ lines. Nitrogen (for STV 7Agl) and Mn (for DP 5690, SG 747, and STV 7Agl) did not follow the general trend of other nutrients of higher nutrient accumulation in $F$ lines. Instead $N$ did not differ between $N$ and $F$ lines in STV 7Agl, and Mn was higher in the $N$ line for DP 5690, but did not differ between $N$ and $F$ lines in SG 747 and STV 7Agl. Except for Mn in DES 119, MD 51ne, and STV 7Agl, and Ca, P, and N for DP 5690, $\mathrm{N}$ and $\mathrm{S}$ and all minerals in leaves were higher in $N$ lines than in $F$ lines (Table 4). When the data were expressed across all lines for the fuzz trait ( $F$ vs. $N$ ) (Figures 1, 2), oil, C, and Ca, were higher in cottonseed in $N$ lines than in $F$ lines, but protein and other minerals, except $\mathrm{Mn}$, were higher in $F$ lines than in $N$ lines, supporting data expressed on line set basis. Fuzzless and fuzzy lines had similar concentrations of $\mathrm{Mn}$.

The higher accumulation of nutrients of $N$ lines than $F$ lines in leaves was also observed when all $F$ lines were compared with all $N$ lines, except for Mn (Figure 3). Each line set accumulated different levels of protein, oil, or other nutrients, and the level ranged from about $197 \mathrm{~g} \mathrm{~kg}^{-1}$ to $287 \mathrm{~g} \mathrm{~kg}^{-1}$ for protein, and $234 \mathrm{~g} \mathrm{~kg}^{-1}$ to $293 \mathrm{~g} \mathrm{~kg}^{-1}$ for oil. Similar wider ranges of other nutrients were observed between $F$ and $N$ lines. Cotton leaves accumulated higher concentrations of nutrients in $N$ lines than in $F$ lines, except for $\mathrm{Ca}$ and $\mathrm{P}$ in DP 5690, and $\mathrm{Mn}$ in DES 119, MD 51ne, and STV 7Agl (Table 4). Generally, both the fuzzless parent (SA 243) and the commercial cultivar DP 444 BG/RR accumulated comparable levels of nutrients to the isogenic lines sets.

Nutrient accumulation in lint differed between $N$ and $F$ lines (Table 5). Some $N$ lines accumulated more nutrients in the lint than their equivalent $F$ lines, and other $N$ lines accumulated less nutrients than their equivalent $F$ lines, reflecting genotypic differences in nutrient accumulations in lint. For example, Ca, K, S, B, $\mathrm{Fe}$, and $\mathrm{Na}$ contents were higher in $N$ lines than in $F$ lines, except in MD 51ne and SG 747 for K, DP 5690 and DES 119 for S, SG 747 and DP 5690 for B, DP 5690 for Fe, and MD 51ne for Na. All lines had at least one nutrient where $F$ line was higher than $N$ line, with the exception of MD 51ne where the $N$ line was always higher or equal to the $F$ line. Generally, a similar trend was also found when data were expressed on fuzz trait basis (all $F$ lines vs. all $N$ lines) (Figure 4).

The higher protein and lower oil concentrations in cottonseed may suggest there is a potential commercial use for fuzzless seed as a source for food (oil) and feed (cottonseed meal). Our results

TABLE 5 | Effect of fuzzless/linted $(N)$ and fuzzy/linted $(F)$ cottonseed phenotypes on cotton lint nutrients Ca, K, Mg, P, C, N, S percentages (\%), and Fe, B, $\mathrm{Mn}, \mathrm{Na}$, and $\mathrm{Zn}$ concentration $\left(\mathrm{mg} \mathrm{kg}^{-1}\right)$.

\begin{tabular}{|c|c|c|c|c|c|c|c|c|c|c|c|c|}
\hline Line & $\mathbf{C a}$ & $\mathbf{K}$ & Mg & $\mathbf{P}$ & C & $\mathbf{N}$ & $\mathbf{S}$ & B & $\mathrm{Fe}$ & Mn & $\mathrm{Na}$ & Zn \\
\hline SA 243 & $0.07 \mathrm{f}$ & $0.48 \mathrm{a}$ & 0.06 de & $0.03 \mathrm{bc}$ & $44.3 \mathrm{a}$ & $0.74 \mathrm{~g}$ & $0.030 \mathrm{e}$ & $3.1 \mathrm{de}$ & 7.1 ef & $3.2 \mathrm{e}$ & $40.5 \mathrm{c}$ & 3.8 ef \\
\hline DP 444 BG/RR & 0.09 e & $0.51 \mathrm{~b}$ & $0.07 \mathrm{bc}$ & $0.03 \mathrm{bc}$ & $44.0 \mathrm{bc}$ & $0.97 \mathrm{bcd}$ & 0.033 de & $3.0 \mathrm{e}$ & $6.4 \mathrm{f}$ & $3.7 \mathrm{ed}$ & 31.6 ef & $5.3 a b$ \\
\hline DES $119 N$ & $0.15 \mathrm{c}$ & $0.53 \mathrm{a}$ & $0.07 \mathrm{bc}$ & $0.02 \mathrm{~d}$ & $44.1 \mathrm{bc}$ & 0.88 def & 0.038 bc & $4.1 \mathrm{bc}$ & $9.6 \mathrm{c}$ & $5.0 \mathrm{bc}$ & $52.4 \mathrm{a}$ & $4.1 \mathrm{de}$ \\
\hline DES $119 F$ & $0.06 \mathrm{f}$ & $0.46 \mathrm{e}$ & $0.06 \mathrm{c}$ & $0.03 \mathrm{a}$ & 43.8 de & $1.05 a b$ & $0.035 \mathrm{~cd}$ & $2.7 \mathrm{e}$ & 7.0 ef & $4.1 \mathrm{~d}$ & $41.2 \mathrm{bc}$ & $5.5 \mathrm{a}$ \\
\hline DP $5690 N$ & $0.11 \mathrm{~d}$ & $0.50 \mathrm{~b}$ & $0.07 \mathrm{~b}$ & $0.02 \mathrm{~cd}$ & 43.9 cde & $0.79 \mathrm{fg}$ & $0.030 \mathrm{e}$ & 3.3 de & 6.8 ef & $4.6 \mathrm{c}$ & $53.0 \mathrm{a}$ & $3.3 f$ \\
\hline DP $5690 F$ & 0.07 ef & $0.46 \mathrm{e}$ & $0.07 \mathrm{~b}$ & $0.02 d$ & $44.1 \mathrm{bc}$ & 0.96 bcde & $0.030 \mathrm{e}$ & $2.9 \mathrm{e}$ & $8.5 \mathrm{~d}$ & $4.8 \mathrm{c}$ & $45.9 \mathrm{~b}$ & $4.1 \mathrm{de}$ \\
\hline MD 51neN & $0.19 \mathrm{a}$ & 0.47 de & $0.06 \mathrm{c}$ & $0.03 \mathrm{~b}$ & 44.0 cde & $0.84 \mathrm{f}$ & $0.053 \mathrm{a}$ & $4.5 \mathrm{~b}$ & $11.1 \mathrm{~b}$ & $6.6 \mathrm{a}$ & 33.2 ef & $5.2 \mathrm{ab}$ \\
\hline MD 51ne $F$ & $0.09 \mathrm{e}$ & 0.47 cde & $0.05 \mathrm{e}$ & $0.02 \mathrm{~cd}$ & $44.1 \mathrm{bc}$ & 0.87 ef & $0.038 \mathrm{bc}$ & $3.0 \mathrm{e}$ & 6.7 ef & $4.7 \mathrm{c}$ & 34.1 de & $4.5 \mathrm{~cd}$ \\
\hline SG $747 N$ & $0.11 d$ & $0.43 \mathrm{f}$ & $0.06 \mathrm{c}$ & $0.02 \mathrm{~d}$ & 44.0 cde & 0.95 cde & $0.038 \mathrm{bc}$ & $3.0 \mathrm{e}$ & $9.1 \mathrm{~cd}$ & $3.7 \mathrm{ed}$ & $39.2 \mathrm{~cd}$ & $5.2 \mathrm{ab}$ \\
\hline SG $747 F$ & 0.09 e & $0.43 f$ & $0.06 d$ & $0.03 b$ & $44.0 \mathrm{cb}$ & $0.99 \mathrm{abc}$ & 0.033 de & $3.6 \mathrm{~cd}$ & $7.4 \mathrm{e}$ & $4.1 \mathrm{~d}$ & $26.3 \mathrm{fg}$ & 4.3 cde \\
\hline STV 7 Agl $N$ & $0.17 \mathrm{~b}$ & $0.54 \mathrm{a}$ & $0.08 \mathrm{a}$ & $0.02 \mathrm{~cd}$ & $43.8 \mathrm{e}$ & $1.09 \mathrm{a}$ & $0.040 \mathrm{~b}$ & $5.9 \mathrm{a}$ & $14.0 \mathrm{a}$ & $5.4 \mathrm{~b}$ & 33.7 ef & $4.5 \mathrm{~cd}$ \\
\hline STV 7Agl F & 0.07 ef & 0.48 cde & $0.07 \mathrm{bc}$ & $0.03 \mathrm{~b}$ & $44.1 \mathrm{bc}$ & $0.79 \mathrm{fg}$ & $0.030 \mathrm{e}$ & $2.8 \mathrm{e}$ & 6.7 ef & $3.4 \mathrm{e}$ & $23.6 \mathrm{~g}$ & $4.7 \mathrm{bc}$ \\
\hline
\end{tabular}



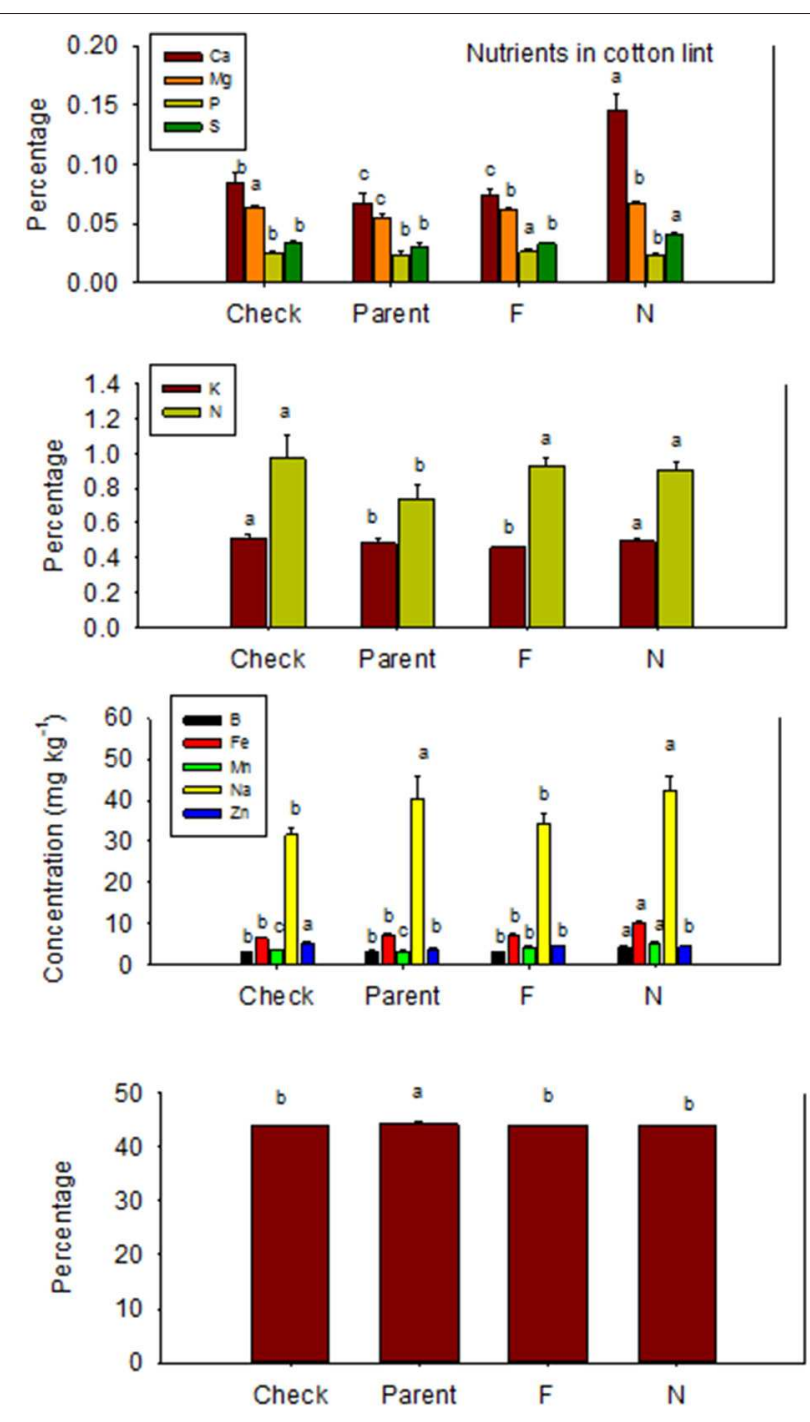

FIGURE 4 | Effects of cottonseed fuzz trait on cotton lint nutrients in near-isogenic Gossypium hirsutum lines expressing fuzzy/linted $(F)$ and fuzzless/linted $(N)$ seed phenotypes, the fuzzless/linted parent SA 243 (parent), and the fuzzy/linted commercial cultivar DP 444 BG/RR (check). Cotton was grown in the field in 2013 only in Stoneville, MS, USA. Bars show means \pm standard error of the mean (SE). Within each constituent, means with the same letter are not significantly different at $5 \%$ as determined by Fisher's LSD test.

are in agreement with previous reports (Bechere et al., 2009). They developed homozygous naked-tufted $\mathrm{M}_{8}$ mutant lines and evaluated the developed lines for lint yield, fiber quality, seed oil content, ginning efficiency, and yarn spinning. They found that lint yield in the naked-tufted seed mutants was lower when compared with their original fuzzy parents. Also, they found that seed oil content in naked-tufted seed mutants was higher than fuzzy parents. Bellaloui and Turley (2013), working on similar material with the same trait, but under greenhouse conditions, and found, generally, that fuzzless cotton seeds accumulated higher oil and lower protein compared with their equivalent fuzzy seeds, showing an inverse relationship between protein and oil. The inverse relationship between protein and oil was previously reported in other species such as corn (Kebede et al., 2013), soybean (Burton, 1985; Ray et al., 2006; Bellaloui et al., 2013a,b), and cottonseed (Pettigrew and Dowd, 2011). Pettigrew and Dowd (2011) investigated the effect of irrigation and planting dates on seed oil and protein in six conventional cotton (Gossypium hirsutum) cultivars (DP 445BR, DP 555BR, FM 800BR, FM 960BR, ST 4892BR, and ST 5599BR), planted at late April and late May, and under irrigated and non-irrigated (dryland) field conditions in Stoneville, MS, from 2005 to 2008. They found irrigation increased the concentrations of seed oil, but decreased seed protein. However, under dryland conditions, protein was higher than oil at late April and late May planting. Their results showed opposite trend between protein and oil, agreeing with the current results.

The higher accumulation of some nutrients in seeds of $F$ lines than in $N$ lines, and the higher accumulation of some other nutrients in $N$ lines than in $F$ lines was also previously reported (Bellaloui and Turley, 2013), and this could be due to genotypic differences. The consistent higher accumulation of nutrients in leaves of $N$ lines than in $F$ lines across line sets suggests limited translocation of nutrients from leaves to seed, and this may explain the lower accumulation of minerals in seeds of some fuzzless isolines. For example, B showed higher accumulation in leaves and lower accumulation in seed of $N$ lines than in the $F$ lines. It is known that cotton has higher B requirement for growth, development, and seed quality. Although B is mobile in sugar-alcohol containing species such as rice, pears, almond, and celery, it looks like B in cotton has limited mobility (Brown and Shelp, 1997; Brown et al., 2002; Dordas, 2006) from leaves to seed. Although high concentrations of B occurred in leaves (ranged from 40 to $55 \mathrm{mg} \mathrm{B} \mathrm{kg}-1$ ), cottonseed contained limited concentrations of $\mathrm{B}\left(<20 \mathrm{mg} \mathrm{B} \mathrm{kg}^{-1}\right)$. Soil used in our experiment had adequate $B$ concentration (ranged from 1.5 to $2.0 \mathrm{mg} \mathrm{kg}^{-1}$ ) to support the crop. The limited mobility of B in cotton may be one reason of why cotton sometimes responds to foliar B application. Dordas (2006) investigated the foliar application of B on cotton and found there was an increase in cotton lint, and concluded that it is possible that the critical levels of B in cotton have been assessed by visual symptoms and not by yield of comparative field studies. It must be noted also that some other studies did not find a positive response to foliar B applications (Heitholt, 1994).

The other mineral that showed an interesting pattern was $\mathrm{Ca}$. The accumulation of $\mathrm{Ca}$ in leaves, seeds, and lint was higher in $N$ lines than in $F$ lines, and this could be explained by the fact that Ca taken up was not used for further physiological and biochemical processing involved in lint fiber development and structure such as the synthesis of cell wall polysaccharides and fatty acids (Gou et al., 2007; Yang et al., 2008; Pang et al., 2010a,b) and the secondary cell wall synthesis (Li et al., 2002, 2005; Wang et al., 2010; Wang and Ruan, 2010). Also, the down-regulation of calcium and phytohormone mediated signals observed at fiber initiation stage in the fuzzless mutants (Padmalatha et al., 2012) could explain the higher levels of $\mathrm{Ca}$ in leaves, seeds, and lint due to lower requirements of $\mathrm{Ca}$ by fuzzless seed lines. The significant role of $\mathrm{Ca}$ in cotton was previously reported and involved 
in pollen germination (Brewbaker and Kwack, 1963), pollen tube growth (Zhang et al., 1997), stimulation of fertilization (Faure et al., 1994; Tian and Russell, 1997), and egg activation (Digonnet et al., 1997), and this is because $\mathrm{Ca}$ is required for vesicle fusion at the tip of the elongating tube (Pierson et al., 1996). It was also found that $\mathrm{Ca}$ enhances the antioxidant enzyme activity and protects the plant under oxidative stress conditions through reactive oxygen species (ROS) scavenging (Jiang and Huang, 2001). The apparent explanation that seed $\mathrm{Ca}$ in $N$ lines was higher than in $F$ lines could be due to higher requirements of $\mathrm{Ca}$ by $N$ lines for physiological and structural functions, may be, for seed protection from severe environmental conditions such as drought and high heat as seeds in $N$ lines are covered with little lint compared with $F$ lines. If this is the case, then germination rate between $N$ and $F$ lines should be different as seed of $N$ lines may be more hard seeded because of the higher $\mathrm{Ca}$ accumulation. The higher Ca content in leaves and lint may support the higher
Ca requirement by $N$ lines compared with $\mathrm{F}$ lines. Because the current results showed higher $\mathrm{Ca}$ in leaves and seeds in $N$ lines than in $F$ lines, it would be worthwhile to further investigate the effects of Ca supply on Ca partitioning in different plant tissues, including seeds and relate that to the rate of ROS enzymes and germination rates.

\section{Correlations Between Nutrients in Fuzzless and Fuzzy Near-Isogenic Lines}

In $N$ lines, protein was positively correlated with $\mathrm{Ca}, \mathrm{B}, \mathrm{Fe}, \mathrm{Mn}$, and $\mathrm{Zn}$, and oil was positively correlated with $\mathrm{C}$ (Table 6). There were positive correlations between $\mathrm{Ca}$ and $\mathrm{K}, \mathrm{Mg}, \mathrm{P}, \mathrm{B}, \mathrm{Fe}, \mathrm{Mn}$, and $\mathrm{Zn}$, and positive correlations between $\mathrm{Mg}$ and $\mathrm{P}, \mathrm{B}, \mathrm{Fe}, \mathrm{Mn}$, and $\mathrm{Zn}$. Positive correlations were observed between $\mathrm{P}$ and $\mathrm{B}, \mathrm{Fe}$, $\mathrm{Mn}$, and $\mathrm{Zn}$, and between $\mathrm{S}$ and $\mathrm{Mn}$. Boron was positively correlated with $\mathrm{Fe}, \mathrm{Mn}$, and $\mathrm{Zn}$, and $\mathrm{Fe}$ had a positive correlation with $\mathrm{Mn}$ and $\mathrm{Zn}$. A positive correlation between $\mathrm{Mn}$ and $\mathrm{Zn}$ was also

TABLE 6 | Pearson correlation coefficient ( $R$ - and P-values) between nutrients in cottonseed of near-isogenic Gossypium hirsutum lines expressing the fuzzless/linted seed phenotype across 2012 and 2013.

\begin{tabular}{|c|c|c|c|c|c|c|c|c|c|c|c|c|c|c|}
\hline & & Protein & Oil & $\mathrm{Ca}$ & $\mathbf{K}$ & Mg & $\mathbf{P}$ & C & $\mathbf{N}$ & $\mathbf{S}$ & B & $\mathrm{Fe}$ & Mn & $\mathrm{Zn}$ \\
\hline \multirow[t]{2}{*}{ Protein } & $R$ & 1 & & & & & & & & & & & & \\
\hline & $P$ & & & & & & & & & & & & & \\
\hline \multirow[t]{2}{*}{ Oil } & $R$ & NS & 1 & & & & & & & & & & & \\
\hline & $P$ & & & & & & & & & & & & & \\
\hline \multirow[t]{2}{*}{$\mathrm{Ca}$} & $R$ & 0.63 & NS & 1 & & & & & & & & & & \\
\hline & $P$ & $* * \star$ & & & & & & & & & & & & \\
\hline \multirow[t]{2}{*}{ K } & $R$ & NS & NS & 0.36 & 1 & & & & & & & & & \\
\hline & $P$ & & & * & & & & & & & & & & \\
\hline \multirow[t]{2}{*}{$\mathrm{Mg}$} & $R$ & NS & NS & 0.52 & 0.54 & 1 & & & & & & & & \\
\hline & $P$ & & & 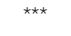 & $* \star *$ & & & & & & & & & \\
\hline \multirow[t]{2}{*}{$P$} & $R$ & NS & NS & 0.58 & 0.61 & 0.92 & 1 & & & & & & & \\
\hline & $P$ & & & $* \star *$ & $* \star *$ & $\star * \star$ & & & & & & & & \\
\hline \multirow[t]{2}{*}{ C } & $R$ & NS & 0.41 & NS & NS & NS & NS & 1 & & & & & & \\
\hline & $P$ & & ** & & NS & & NS & & & & & & & \\
\hline \multirow[t]{2}{*}{$N$} & $R$ & NS & NS & NS & NS & NS & NS & NS & 1 & & & & & \\
\hline & $P$ & & & & & & NS & & & & & & & \\
\hline \multirow[t]{2}{*}{ S } & $R$ & NS & NS & NS & NS & NS & NS & NS & NS & 1 & & & & \\
\hline & $P$ & & & & & & NS & & & & & & & \\
\hline \multirow[t]{2}{*}{$B$} & $R$ & 0.49 & NS & 0.70 & NS & 0.77 & 0.73 & NS & NS & NS & 1 & & & \\
\hline & $P$ & $\star *$ & & $* \star \star$ & & $* * *$ & $\star * \star$ & & & & & & & \\
\hline \multirow[t]{2}{*}{$\mathrm{Fe}$} & $R$ & 0.51 & NS & 0.65 & 0.40 & 0.75 & 0.71 & NS & NS & NS & 0.74 & 1 & & \\
\hline & $P$ & $* * *$ & & 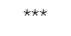 & * & $* * \star$ & $* * \star$ & & & & $* * \star$ & & & \\
\hline \multirow[t]{2}{*}{$\mathrm{Mn}$} & $R$ & 0.40 & NS & 0.49 & NS & 0.38 & 0.35 & NS & NS & 0.30 & 0.51 & 0.45 & 1 & \\
\hline & $P$ & * & & $\star \star$ & & * & $\star$ & & & * & $* * *$ & ** & & \\
\hline \multirow[t]{2}{*}{$\mathrm{Zn}$} & $R$ & 0.31 & NS & 0.65 & NS & 0.59 & 0.50 & NS & NS & NS & 0.75 & 0.62 & 0.41 & 1 \\
\hline & $P$ & * & & 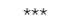 & & 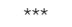 & $\star *$ & & & & 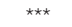 & 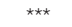 & $\star \star$ & \\
\hline
\end{tabular}

$N=40 ;{ }^{*} p \leq 0.5 ;{ }^{* *} p \leq 0.01 ;{ }^{* * *} p \leq 0.001$ 
TABLE 7 | Table 6 Pearson correlation coefficient ( $R$ - and $P$-values) between nutrients in cottonseed of near-isogenic Gossypium hirsutum lines expressing the fuzzy/linted seed phenotype across 2012 and 2013.

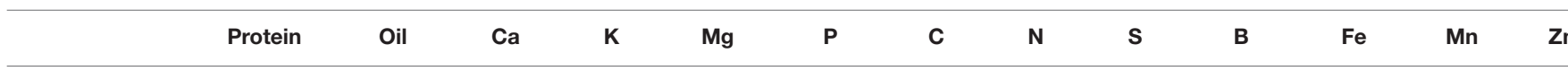

\section{Protein}

1

\begin{tabular}{|c|c|c|c|c|c|c|c|c|c|c|c|c|c|c|}
\hline Oil & $\begin{array}{l}R \\
P\end{array}$ & NS & 1 & & & & & & & & & & & \\
\hline \multirow[t]{2}{*}{$\mathrm{Ca}$} & $R$ & 0.41 & & 1 & & & & & & & & & & \\
\hline & $P$ & $\star *$ & & & & & & & & & & & & \\
\hline \multirow[t]{2}{*}{ K } & $R$ & NS & NS & NS & 1 & & & & & & & & & \\
\hline & $P$ & & & & & & & & & & & & & \\
\hline \multirow[t]{2}{*}{$\mathrm{Mg}$} & $R$ & NS & NS & NS & NS & 1 & & & & & & & & \\
\hline & $P$ & & & & & & & & & & & & & \\
\hline \multirow[t]{2}{*}{$P$} & $R$ & NS & NS & NS & NS & 0.95 & 1 & & & & & & & \\
\hline & $P$ & & & & & $* * \star$ & & & & & & & & \\
\hline \multirow[t]{2}{*}{ C } & $R$ & NS & NS & NS & NS & NS & NS & 1 & & & & & & \\
\hline & $P$ & & & & & & & & & & & & & \\
\hline \multirow[t]{2}{*}{$\mathrm{N}$} & $R$ & NS & NS & NS & NS & NS & NS & NS & 1 & & & & & \\
\hline & $P$ & & & & & & & & & & & & & \\
\hline \multirow[t]{2}{*}{ S } & $R$ & NS & NS & NS & NS & NS & NS & NS & NS & 1 & & & & \\
\hline & $P$ & & & & & & & & & & & & & \\
\hline \multirow[t]{2}{*}{ B } & $R$ & 0.50 & NS & 0.41 & NS & 0.46 & 0.44 & NS & NS & NS & 1 & & & \\
\hline & $P$ & 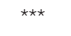 & & * & & $* *$ & $* *$ & & & & & & & \\
\hline \multirow[t]{2}{*}{$\mathrm{Fe}$} & $R$ & NS & NS & NS & NS & 0.62 & 0.58 & NS & NS & NS & 0.54 & 1 & & \\
\hline & $P$ & & & & & $\star * \star$ & $* \star *$ & & & & $* * *$ & & & \\
\hline \multirow[t]{2}{*}{$\mathrm{Mn}$} & $R$ & NS & NS & 0.36 & NS & 0.54 & 0.51 & NS & NS & NS & 0.61 & 0.67 & 1 & \\
\hline & $P$ & & & * & & $\star \star \star *$ & 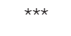 & & & & 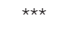 & $* \star *$ & & \\
\hline \multirow[t]{2}{*}{$\mathrm{Zn}$} & $R$ & NS & 0.37 & NS & NS & NS & NS & NS & NS & NS & NS & 0.31 & & 1 \\
\hline & $P$ & & $\star$ & & & & & & & & & * & & \\
\hline
\end{tabular}

$N=40 ;{ }^{*} p \leq 0.5 ;{ }^{* *} p \leq 0.01 ;{ }^{* \star *} p \leq 0.001$.

observed. In $F$ lines, positive correlations between protein and $\mathrm{B}$, and between protein and $\mathrm{Ca}$ were observed (Table 7). Oil was positively correlated with $\mathrm{Zn}$, and $\mathrm{Ca}$ had a positive correlation with $\mathrm{B}$ and $\mathrm{Mn}$. Both $\mathrm{Mg}$ and $\mathrm{P}$ had positive correlation with $\mathrm{B}$, $\mathrm{Fe}$, and Mn. Boron had positive correlations with Fe and Mn, and $\mathrm{Fe}$ had positive correlations with $\mathrm{Mn}$ and $\mathrm{Zn}$.

Correlation between nutrients in $N$ lines and $F$ lines showed significant positive correlation between some nutrients in both $N$ and $F$ lines, but some nutrients did not correlate (Tables 6, 7). For example, in $N$ lines protein was positively correlated with $\mathrm{Ca}, \mathrm{B}, \mathrm{Fe}, \mathrm{Mn}$, and $\mathrm{Zn}$, suggesting the indirect involvement of these minerals with protein synthesis. Also, the positive correlations between $\mathrm{Ca}$ and oil, and between $\mathrm{C}$ and oil support the observation of similar trends of these nutrients in $N$ lines, and the involvement of carbon in oil metabolism. Nutrients such as
P, Ca, and B; Ca, B, and Mn; Mg, B, Fe, and Mn; P, B, and Mn; $\mathrm{Fe}, \mathrm{Mn}$, and $\mathrm{Zn}$ showed consistency of positive correlation in both $N$ and $F$ lines. Other nutrients were not consistent between $N$ and $F$ lines, and this is due to genotypic effects. The positive and negative correlation between cation and anion nutrients were previously reported, although this correlation depends on growth conditions, genotype, and nutrient supply (Mengel and Kirkby, 1982; Marschner, 2012).

Nutrient uptake, translocation, redistribution, and accumulation are processes controlling the accumulation of minerals in seeds (Grusak and DellaPenna, 1999; White and Broadley, 2005), and most of the genetic basis of these process are still not known (Ding et al., 2010). Previous research on fuzzless cottonseed showed that fiber development involves physiological, biochemical, and molecular processes (Turley et al., 2007; 

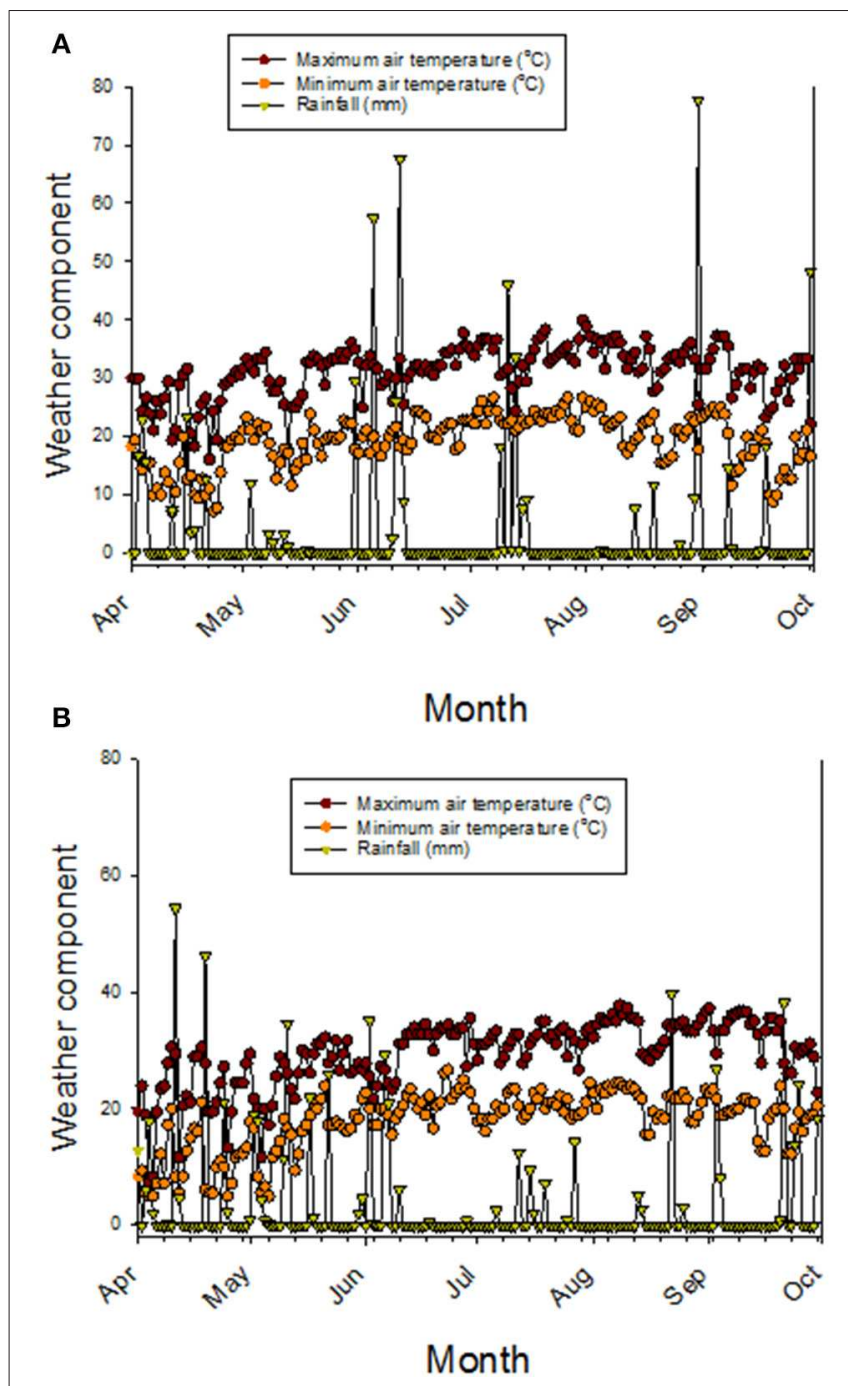

FIGURE 5 | Maximum and minimum air temperatures, and precipitation (rainfall) in 2012 (A) and in 2013 (B). Weather data obtained from MSUCares, Stoneville (2015).

Padmalatha et al., 2012). For example, it was found that the fiber development involved processes related to genetics (Turley and Kloth, 2002; Gou et al., 2007; Turley et al., 2007; Zhao et al., 2009; Liu et al., 2012), phytohormones (Yang et al., 2006; Zhang et al., 2011), transcription factors such as MYB25 (Machado et al., 2009), turgor mechanism (Ruan et al., 2003; Wang et al., 2010; Wang and Ruan, 2010), soluble sugars, potassium, and organic acids, ion-transporters ( $\mathrm{H}+$-ATPases and $\mathrm{K}+$-transporter) (Wang et al., 2010; Wang and Ruan, 2010); upregulation of potassium and sugar transporters to maintain the turgor pressure (Ruan et al., 2004), carbohydrate and energy metabolism and carbon skeletons for the synthesis of cell wall polysaccharides and fatty acids (Gou et al., 2007; Yang et al., 2008; Pang et al., 2010a,b), and the secondary cell wall synthesis (Li et al., 2002, 2005; Wang et al., 2010; Wang and Ruan, 2010). Because these processes were involved in fiber development, then it is expected to have differences in phenotypic traits such as protein, oil, and minerals between fuzzy and fuzzless cottonseed. This is because of the involvement of carbon skeleton and energy metabolism (Gou et al., 2007; Yang et al., 2008; Pang et al., 2010a,b), K (Ruan et al., 2004; Wang et al., 2010), and Ca (Padmalatha et al., 2012) in fiber development. The only difference between each line set investigated here is cottonseed fuzz trait, so differences in cottonseed composition constituents observed in our study could be explained by the trait as each isoline set has the same genetic background (Bellaloui and Turley, 2013). It must be noted here that information explaining nutrient dynamics in fuzzy and fuzzless cottonseed is almost non-existent (Bellaloui and Turley, 2013), and most of research on fuzzless cottonseed has been on cell biology, genetic, and molecular biology (Padmalatha et al., 2012; Bellaloui and Turley, 2013). However, it is possible that cottonseed differences could be explained by stored energy metabolism differences such as sugars, hormones signaling, and lower lint yields (Turley et al., 2007; Stetina et al., 2014) in fuzzless mutants. These major down regulations, mentioned above, and lower lint yield may have led to a nutrient imbalance, resulting in differences in nutrient uptake, transport, mobility from leaves (source) to seed (sink), and nutrient accumulation in leaves and cottonseed between $N$ and $F$ isogenic lines during boll development. The weather data (Figures 5A,B) showed that during May-August (reproduction stage period for cotton), the maximum and minimum temperatures in 2012 were higher than in 2013. For example, maximum temperatures in 2012 in May, June, July, August, and September were, respectively, $30.9,31.7,33.9$, and $33.8^{\circ} \mathrm{C}$ vs. $26.2,30.4,31.5$, and $33.8^{\circ} \mathrm{C}$ in 2013. Rainfall (mm) was higher in April and May in 2013 than in 2012, but in June, July, August, generally the rainfall was higher in 2012 than in 2013. Bearing in mind the rainfall in 1 day can reach upto $77 \mathrm{~mm}$ (for example in 2012 in August) or upto $40 \mathrm{~mm}$ (for example, in August in 2013). It is clear that the different patterns in temperature and rainfall between years (Figures 5A,B) will impact soil moisture, and consequently nutrient uptake, transport, and accumulation of nutrients in seeds. The effect of rainfall and temperatures in each year could be minimum since the experiment was irrigated and all genotypes were exposed to the same growing conditions. However, we still do not know the response of $F$ and $N$ genotypes or genotypes in each isoline set (fuzzy or fuzzless) to soil moisture resulted from rainfall or higher temperatures and their effects on nutrients uptake and transport. Therefore, we cannot exclude the effect of weather conditions on seed nutrients accumulation in $F$ and $N$ genotypes or on genotypes in the two sets of isolines. Further research is needed to determine the response of $F$ and $N$ genotypes to growing conditions such as drought and heat under field conditions.

It appears that the higher accumulation of nutrients of most $N$ lines in their leaves and lower accumulation of nutrients $(\mathrm{N}$, $\mathrm{S}$, and minerals) in seeds of some of the $F$ lines could be due to limited mobility of the nutrients from leaves to seed and lower nutrients demand by seeds of these $N$ line, resulting in higher accumulation of nutrients in leaves. Some $N$ lines did not follow this pattern, and this could be due to genotypic differences and fuzz trait. The real mechanism of how the fuzz development is involved in differential nutrients between $N$ and $F$ lines are still 
not understood (Bellaloui and Turley, 2013), and further research on the effects of nutrient supply on nutrient mobility is needed. Also, research is underway, and more biochemical and cellular methods including gene expression profiling based on RNA sequencing will be used to identify the gene responsible for this trait.

\section{Conclusions}

The current research demonstrated that seed protein was higher in fuzzy genotype in all near-isogenic sets, but seed oil was higher in fuzzless genotype in all near-isogenic sets, suggesting possible commercial use for fuzzless seed as source of both protein or oil as the level of protein and oil was competitive with the commercial check. The higher carbon in all fuzzless cottonseed may indicate that higher energy-storage occurred in fuzzless cottonseed. The higher accumulation of most of nutrients in leaves of fuzzless lines and lower accumulation of these nutrients in cottonseed suggested limited mobility and translocation of these nutrients in fuzzless lines compared with fuzzy lines. The research demonstrated that fuzz fiber development altered cottonseed composition, and this may be due to the

\section{References}

Analytical Methods Committee (1959). Analysts. Her majesty's stationery office, London. 84, 214.

Arpat, A. B., Waugh, M., Sullivan, J. P., Gonzales, M., Frisch, D., Main, D., et al. (2004). Functional genomics of cell elongation in developing cotton fibers. Plant Mol. Biol. 54, 911-929. doi: 10.1007/s11103-004-0392-y

Association of Official Analytical Chemists (AOAC), (1990a). "Method 988.05," in Official Methods of Analysis, 15th Edn., ed K. Helrich (Arlington, VA: AOAC), 70

Association of Official Analytical Chemists (AOAC), (1990b). "Method 920.39," in Official Methods of Analysis, 15th Edn., ed K. Helrich (Arlington, VA: AOAC), 79.

Bandemer, S. L., and Schaible, P. J. (1944). Determination of iron. A study of the o-phenanthroline method. Ind. Eng. Chem. Anal. Ed. 16, 317-319. doi: $10.1021 / \mathrm{i} 560129 \mathrm{a} 013$

Bechere, E., Auld, D. L., and Hequet, E. (2009). Development of 'naked-tufted' seed coat mutants for potential use in cotton production. Euphytica 167, 333-339. doi: 10.1007/s10681-009-9890-y

Bellaloui, N., Gillen, A. M., Mengistu, A., Kebede, H., Fisher, D. K., Smith, J. R., et al. (2013a). Responses of nitrogen metabolism and seed nutrition to drought stress in soybean genotypes differing in slow-wilting phenotype. Front. Plant Sci. 4:498. doi: 10.3389/fpls.2013.00498

Bellaloui, N., Hanks, J. E., Fisher, D. K. and Mengistub, A. (2009). Soybean seed composition is influenced by within-field variability in soil nutrients. Plant Manag. Netw. 8. doi: 10.1094/CM-2009-1203-01-RS

Bellaloui, N., Hu, Y., Mengistu, A., Kassem, M. A., and Abel, C. A. (2013b). Effects of foliar boron application on seed composition, cell wall boron, and seed $\delta 15 \mathrm{~N}$ and $\delta 13 \mathrm{C}$ isotopes in water-stressed soybean plants. Front. Plant Sci. 4:270. doi: 10.3389/fpls.2013.00270

Bellaloui, N., Mengistu, A., Walker, R. R., and Young, L. D. (2014). Soybean seed composition affected by seeding rates and row spacing in the Midsouth USA. Crop Sci. 54, 1782-1795. doi: 10.2135/cropsci2013.07.0463

Bellaloui, N., Smith, J. R., Gillen, A. M., and Ray, J. D. (2011). Effects of maturity, genotypic background, and temperature on seed mineral composition in near-isogenic soybean lines in the early soybean production system. Crop Sci. 51, 1161-1171. doi: 10.2135/cropsci2010.04.0187 involvement of fuzz fiber development in carbon and nitrogen metabolism, and the mobility of nutrients from leaves (source) to seed (sink). This information is beneficial to breeders for selection for higher oil or higher protein content, and to physiologist to further understand the mechanisms of mineral movement within plants. Understanding the mechanisms of nutrient mobility from leaves to seed would help for selecting for cottonseed with higher nutritional quality for human consumption and animal feed.

\section{Acknowledgments}

Technical support for this project provided by S. Mosley, K. Jordan, and R. Manning is appreciated. Funding for this research was provided by USDA, Agricultural Research Service projects 6066-21220-012-00D, 6066-21000-051-00D, and 6066-22000-074-00D. Mention of trade names or commercial products in this publication is solely for the purpose of providing specific information and does not imply recommendation or endorsement by the Unites States Department of Agriculture (USDA). USDA is an equal opportunity provider and employer.

Bellaloui, N., and Turley, R. B. (2013). Effects of fuzzless cottonseed phenotype on cottonseed nutrient composition in near isogenic cotton (Gossypium hirsutum L.) mutant lines under well-watered and water stress conditions. Front. Plant Sci. 4:516. doi: 10.3389/fpls.2013.00516

Boydak, E., Alpaslan, M., Hayta, M., Gercek, S., and Simsek, M. (2002). Seed composition of soybeans grown in the Harran region of Turkey as affected by row spacing and irrigation. J. Agric. Food Chem. 50, 4718-4720. doi: 10.1021/jf0255331

Brewbaker, J. L., and Kwack, B. H. (1963). The essential role of calcium ion in pollen germination and pollen tube growth. Am. J. Bot. 50, 859-865. doi: $10.2307 / 2439772$

Brown, P. H., Bellaloui, N., Wimmer, M. A., Bassil, E. S., Ruiz, J., Hu, H., et al. (2002). Boron in plant biology. Plant Biol. 4, 205-223. doi: 10.1055/s-200225740

Brown, P. H., and Shelp, B. J. (1997). Boron mobility in plants. Plant Soil 193, 85-101. doi: 10.1023/A:1004211925160

Burton, J. W. (1985). "Breeding soybean for improved protein quantity and quality," in World Soybean Research Conference III: Proceedings, ed R. Shibles (Ames; Boulder: Westview Press), August 12-17. 361-367.

Cavell, A. J. (1955). The colorimetric determination of phosphorus in plant materials. J. Sci. Food Agric. 6, 479-480. doi: 10.1002/jsfa.2740060814

Digonnet, C., Aldon, D., Leduc, N., Dumas, C., and Rougier, M. (1997). First evidence of a calcium transient in flowering plants at fertilization. Dev. Camb. Engl. 124, 2867-2874.

Ding, G., Yang, M., Hu, Y., Liao, Y., Shi, L., and Xu, F. (2010). Quantitative trait loci affecting seed mineral concentrations in Brassica napus grown with contrasting phosphorus supplies. Ann. Bot. 105, 1221-1234. doi: 10.1093/aob/ mcq050

Dordas, C. (2006). Foliar boron application affects lint and seed yield and improves seed quality of cotton grown on calcareous soils. Nutr. Cycl. Agroecosyst. 76, 19-28. doi: 10.1007/s10705-006-9037-7

Faure, J. E., Digonnet, C., and Dumas, C. (1994). An in vitro system for adhesion and fusion of maize gametes. Science 263, 1598-1600. doi: 10.1126/science.263.5153.1598

Fletcher, R. J., Bell, I. P., and Lambert, J. P. (2004). Public health aspects of food fortification: a question of balance. Proc. Nutr. Soc. 63, 605-614. doi: 10.1079/PNS2004391 
Gou, J. Y., Wang, L. J., Chen, S. P., Hu, W. L., and Chen, X. Y. (2007). Gene expression and metabolite profiles of cotton fiber during cell elongation and secondary cell wall synthesis. Cell Res. 17, 422-434. doi: 10.1038/sj.cr. 7310150

Grusak, M. A., and DellaPenna, D. (1999). Improving the nutrient composition of plants to enhance human nutrition and health. Ann. Rev. Plant Physiol. Plant Mol. Biol. 50, 133-161. doi: 10.1146/annurev.arplant.50.1.133

Guan, X., Lee, J. J., Pang, M., Shi, X., Stelly, D. M., and Chen, Z. J. (2011). Activation of Arabidopsis seed hair development by cotton fiber-related genes. PLoS ONE 6:e21301. doi: 10.1371/journal.pone.0021301

He, Z., Shankle, M., Zhang, H., Way, T. R., Tewolde, H., and Uchimiya, M. (2013). Mineral composition of cottonseed is affected by fertilization management practices. Agron. J. 105, 341-350. doi: 10.2134/agronj2012.0351

Heinemann, R. J. B., Fagundes, P. L., Pinto, E. A., Penteado, M. V. C., and LanferMarquez, U. M. (2005). Comparative study of nutrient composition of commercial brown, parboiled and milled rice from Brazil. J. Food Comp. Anal. 18, 287-296. doi: 10.1016/j.jfca.2004.07.005

Heitholt, J. J. (1994). Supplemental boron, boll retention percentage, ovary carbohydrates and lint yield in modern cotton genotypes. Agron. J. 86, 492-497. doi: 10.2134/agronj1994.00021962008600030007x

Ji, S. J., Lu, Y. C., Feng, J. X., Wei, G., Li, J., Shi, Y. H., et al. (2003). Isolation and analyses of genes preferentially expressed during early cotton fiber development by subtractive PCR and cDNA array. Nucleic Acids Res. 31, 2534-2543. doi: $10.1093 /$ nar/gkg358

Jiang, Y., and Huang, B. (2001). Effects of calcium on antioxidant activities and water relations associated with heat tolerance in two cool-season grasses. J. Exp. Bot. 52, 341-349. doi: 10.1093/jexbot/52.355.341

John, M. K., Chuah, H. H., and Neufeld, J. H. (1975). Application of improved azomethine-H method to the determination of boron in soils and plants. Anal. Lett. 8:559-568. doi: 10.1080/00032717508058240

Kebede, H., Abbas, H. K., Fisher, D. K., and Bellaloui, N. (2013). Relationship between aflatoxin contamination and physiological responses of corn plants under drought and heat stress. Toxins 4, 1385-1403. doi: 10.3390/toxins4111385

Li, X. B., Cai, L., Cheng, N. H., and Liu, J. W. (2002). Molecular characterization of the cotton GhTUB1 gene that is preferentially expressed in fiber. Plant Physiol. 130, 666-674. doi: 10.1104/pp.005538

Li, X. B., Fan, X. P., Wang, X. L., Cai, L., and Yang, W. C. (2005). The cotton ACTIN1 gene is functionally expressed in fibers and participates in fiber elongation. Plant Cell 17, 859-875. doi: 10.1105/tpc.104.029629

Liu, K., Han, M., Zhang, C., Yao, L., Sun, J., and Zhang, T. (2012). Comparative proteomic analysis reveals the mechanisms governing cotton fiber differentiation and initiation. J. Proteomics 75, 845-856. doi: 10.1016/j.jprot.2011.09.025

Loeppert, R. L., and Inskeep, W. P. (1996). "Colorimetric determination of ferrous iron and ferric iron by the 1,10-phenanthroline method," in Methods of Soil Analysis: Part 3, Chemical Methods, ed J. M. Bigham (Madison, WI: SSSA), 659-661.

Lohse, G. (1982). Microanalytical azomethine-H method for boron determination in plant tissue. Commun. Soil Sci. Plant Anal. 13, 127-134. doi: 10.1080/00103628209367251

Lu, K., Li, L., Zheng, X., Zhang, Z., Mou, T., and Hu, Z. (2008). Quantitative trait loci controlling $\mathrm{Cu}, \mathrm{Ca}, \mathrm{Zn}, \mathrm{Mn}$ and $\mathrm{Fe}$ content in rice grains. J. Genet. 87, 305-310. doi: 10.1007/s12041-008-0049-8

Machado, A., Wu, Y., Yang, Y., Llewellyn, D. J., and Dennis, E. S. (2009). The MYB transcription factor GhMYB25 regulates early fiber and trichome development. Plant J. 59, 52-62. doi: 10.1111/j.1365-313X.2009.03847.x

Marschner, P. (2012). Marschner's Mineral Nutrition of Higher Plants. 3rd Edn. San Diego, CA: Academic Press.

Mengel, K., and Kirkby, E. A. (1982). Principles of Plant Nutrition, 3rd Edn. Worblaufen; Bern: International Potash Institute.

MSUCares, Stoneville, M. S. (2015). (http://ext.msstate.edu/anr/drec/weather.cgi). Verified on February 10, 2015.

Padmalatha, K. V., Patil, D. P., Kumar, K., Dhandapani, G., Kanakachari, M., Phanindra, M. L. V., et al. (2012). Functional genomics of fuzzless-lintless mutant of Gossypium hirsutum L. cv. MCU5 reveal key genes and pathways involved in cotton fiber initiation and elongation. BMC Genomics 13:624-638. doi: 10.1186/1471-2164-13-624
Pang, C. Y., Wang, H., Pang, Y., Xu, C., Jiao, Y., Qin, Y. M. X., et al. (2010a). Comparative proteomics indicates that biosynthesis of pectic precursors is important for cotton fiber and Arabidopsis root hair elongation. Mol. Cell. Proteomics 9, 2019-2033. doi: 10.1074/mcp.M110.000349

Pang, C. Y., Wang, H., Song, W. Q., and Zhu, Y. X. (2010b). The cotton ATP synthase $\delta 1$ subunit is required to maintain a higher ATP/ADP ratio that facilitates rapid fiber cell elongation. Plant Biol. 12, 903-909. doi: 10.1111/j.14388677.2009.00313.x

Pettigrew, W. T., and Dowd, M. K. (2011). Varying planting dates or irrigation regimes alters cottonseed composition. Crop Sci. 51, 2155-2164. doi: 10.2135/cropsci2011.02.0085

Pierson, E. S., Miller, D. D., Callaham, D. A., van Aken, J., Hackett, G., and Hepler, P. K. (1996). Tip-localized calcium entry fluctuates during pollen tube growth. Dev. Biol. 174, 160-173. doi: 10.1006/dbio.1996.0060

Ray, J. D., Fritschi, F. B., and Heatherly, L. G. (2006). Large application of fertilizer $\mathrm{N}$ at planting affects seed protein and oil concentrations in the early soybean production system. Field Crops Res. 99, 67-74. doi: 10.1016/j.fcr.2006. 03.006

Ruan, Y. L., Llewellyn, D. J., and Furbank, R. T. (2003). Suppression of sucrose synthase gene expression represses cotton fiber cell initiation, elongation, and seed development. Plant Cell 15, 952-964. doi: 10.1105/tpc.010108

Ruan, Y. L., Xu, S. M., White, R., and Furbank, R. T. (2004). Genotypic and developmental evidence for the role of plasmodesmatal regulation in cotton fiber elongation mediated by callose turnover. Plant Physiol. 136, 4104-4113. doi: 10.1104/pp.104.051540

Samman, S., Naghii, M. R., Lyons Wall, P. M., and Verus, A. P. (1998). The nutritional and metabolic effects of boron in humans and animals. Biol. Trace Elem. Res. 66, 227-235. doi: 10.1007/BF02783140

SAS (2002-2012). Statistical Analysis System. (Cary, NC: SAS Institute Inc).

Seagull, R. W., and Giavalis, S. (2004). Pre- and post- anthesis application of exogenous hormones alters fiber production in Gossypium hirsutum L. cultivar Maxxa GTO. J. Cotton Sci. 8, 105-111. Available online at: https://www.cotton.org/journal/2004-08/2/upload/jcs08-105.pdf

Shi, Y. H., Zhu, S. W., Mao, X. Z., Feng, J. X., Qin, Y. M., Zhang, L., et al. (2006) Transcriptome profiling, molecular biological, and physiological studies reveal a major role for ethylene in cotton fiber cell elongation. Plant Cell. 18, 651-664. doi: 10.1105/tpc.105.040303

Stetina, S. R., Turley, R. B., Bellaloui, N., and Boykin, J. C. (2014). Yield and fiber quality of five pairs of near-isogenic cotton (Gossypium hirsutum L.) lines expressing fuzzless/linted and fuzzy/linted seed phenotypes. J. Crop Improv. 28, 680-699. doi: 10.1080/15427528.2014.931901

Stewart, J. M. (1975). Fiber initiation on the cotton ovule (Gossypium hirsutum). Am. J. Bot. 62, 723-730. doi: 10.2307/2442061

Tian, H. Q., and Russell, S. D. (1997). Micromanipulation of male and female gametes of Nicotiana tabacum: II. Preliminary attempts for in vitro fertilization and egg cell culture. Plant Cell Rep. 16, 657-661. doi: 10.1007/BF01275510

Turley, R. B., and Kloth, R. H. (2002). Identification of a third fuzzless seed locus in upland cotton (Gossypium hirsutum L.). J. Hered. 93, 359-364. doi: 10.1093/jhered/93.5.359

Turley, R. B., Vaughn, K. C., and Scheffler, J. A. (2007). Lint development and properties of fifteen fuzzless seed lines of Upland cotton (Gossypium hirsutum L.). Euphytica 156, 57-65. doi: 10.1007/s10681-006-9351-9

Walford, S. A., Wu, Y., Llewellyn, D. J., and Dennis, E. S. (2011). GhMYB25like: a key factor in early cotton fiber development. Plant J. 65, 785-797. doi: 10.1111/j.1365-313X.2010.04464.X

Wang, J., Wang, H. Y., Zhao, P. M., Han, L. B., Jiao, G. L., Zheng, Y. Y., et al. (2010). Overexpression of a profilin (GhPFN2) promotes the progression of developmental phases in cotton fibers. Plant Cell Physiol. 51, 1276-1290. doi: $10.1093 / \mathrm{pcp} / \mathrm{pcq} 086$

Wang, L., and Ruan, Y. L. (2010). Unraveling mechanisms of cell expansion linking solute transport, metabolism, plasmodesmtal gating and cell wall dynamics. Plant Signal. Behav. 5, 1561-1564. doi: 10.4161/psb.5.12.13568

White, P. J., and Broadley, M. R. (2005). Biofortifying crops with essential mineral elements. Trends Plant Sci. 10, 586-593. doi: 10.1016/j.tplants.2005. 10.001

Wilcox, J. R., and Shibles, R. M. (2001). Interrelationships among seed quality attributes in soybean. Crop Sci. 41, 11-14. doi: 10.2135/cropsci2001.41111x 
Wilkins, T. A., and Arpat, A. B. (2005). The cotton fiber transcriptome. Physiol. Plant. 124, 295-300. doi: 10.1111/j.1399-3054.2005.00514.x

Yang, S. S., Cheung, F., Lee, J. J., Ha, M., Wei, N. E., Sze, S. H., et al. (2006). Accumulation of genome-specific transcripts, transcription factors and phytohormonal regulators during early stages of fiber cell development in allotetraploid cotton. Plant J. 47, 761-775. doi: 10.1111/j.1365-313X.2006.02829.x

Yang, Y. W., Bian, S. M., Yao, Y., and Liu, J. Y. (2008). Comparative proteomic analysis provides new insights into the fiber elongating process in cotton. J. Proteome Res. 7, 4623-4637. doi: 10.1021/pr800550q

Yu, J., Yu, S., Fan, S., Song, M., Zhai, H., Li, X., et al. (2012). Mapping quantitative trait loci for cottonseed oil, protein and gossypol content in a Gossypium hirsutum $\times$ Gossypium barbadense backcross inbred line population. Euphytica 187, 191-201. doi: 10.1007/s10681-012-0630-3

Zhang, J. S., Yang, H. Y., Zhu, L., and Tong, H. (1997). Ultracytochemical localization of calcium in the pollen tube track of cotton gynoecium. Acta Bot. Sin. 39, 121-125.

Zhang, M. W., Guo, B. J., and Peng, Z. M. (2004). Genetic effects on $\mathrm{Fe}, \mathrm{Zn}, \mathrm{Mn}$ and $\mathrm{P}$ contents in indica black pericarp rice and their genetic correlations with grain characteristics. Euphytica 135, 315-323. doi: 10.1023/B:EUPH.0000013340.98344.60
Zhang, M., Zheng, X., Song, S., Zeng, Q., Hou, L., Li, D., et al. (2011). Spatiotemporal manipulation of auxin biosynthesis in cotton ovule epidermal cells enhances fiber yield and quality. Nat. Biotechnol. 29, 453-458. doi: 10.1038/ nbt. 1843

Zhao, P. M., Wang, L. L., Han, L. B., Wang, J., Yao, Y., Wang, H. Y., et al. (2009). Proteomic identification of differentially expressed proteins in the ligon lintless mutant of upland cotton (Gossypium hirsutum L.). J. Proteome Res. 9, 1076-1087. doi: 10.1021/pr900975t

Conflict of Interest Statement: The authors declare that the research was conducted in the absence of any commercial or financial relationships that could be construed as a potential conflict of interest.

Copyright (c) 2015 Bellaloui, Stetina and Turley. This is an open-access article distributed under the terms of the Creative Commons Attribution License (CC BY). The use, distribution or reproduction in other forums is permitted, provided the original author(s) or licensor are credited and that the original publication in this journal is cited, in accordance with accepted academic practice. No use, distribution or reproduction is permitted which does not comply with these terms. 